\title{
Subsurface Geometry of the San Andreas Fault in Southern California: Results from the Salton Seismic Imaging Project (SSIP) and Strong Ground Motion Expectations
}

\author{
by Gary S. Fuis, Klaus Bauer, Mark R. Goldman, Trond Ryberg, Victoria E. Langenheim, \\ Daniel S. Scheirer, Michael J. Rymer, Joann M. Stock, John A. Hole, Rufus D. Catchings, \\ Robert W. Graves, and Brad Aagaard
}

\begin{abstract}
The San Andreas fault (SAF) is one of the most studied strike-slip faults in the world; yet its subsurface geometry is still uncertain in most locations. The Salton Seismic Imaging Project (SSIP) was undertaken to image the structure surrounding the SAF and also its subsurface geometry. We present SSIP studies at two locations in the Coachella Valley of the northern Salton trough. On our line 4, a fault-crossing profile just north of the Salton Sea, sedimentary basin depth reaches $4 \mathrm{~km}$ southwest of the SAF. On our line 6, a fault-crossing profile at the north end of the Coachella Valley, sedimentary basin depth is $\sim 2-3 \mathrm{~km}$ and centered on the central, most active trace of the SAF. Subsurface geometry of the SAF and nearby faults along these two lines is determined using a new method of seismic-reflection imaging, combined with potential-field studies and earthquakes. Below a 6-9 km depth range, the SAF dips $\sim 50^{\circ}-60^{\circ} \mathrm{NE}$, and above this depth range it dips more steeply. Nearby faults are also imaged in the upper $10 \mathrm{~km}$, many of which dip steeply and project to mapped surface fault traces. These secondary faults may join the SAF at depths below about $10 \mathrm{~km}$ to form a flower-like structure. In Appendix $\mathrm{D}$, we show that rupture on a northeast-dipping SAF, using a single plane that approximates the two dips seen in our study, produces shaking that differs from shaking calculated for the Great California ShakeOut, for which the southern SAF was modeled as vertical in most places: shorter-period $(T<1 \mathrm{~s})$ shaking is increased locally by up to a factor of 2 on the hanging wall and is decreased locally by up to a factor of 2 on the footwall, compared to shaking calculated for a vertical fault.
\end{abstract}

\section{Introduction}

The southern part of the San Andreas fault (SAF), from the Coachella Valley to the Mojave Desert, is one of California's (and the United States') greatest natural hazards (Jones et al., 2008). The SAF in the Coachella Valley has not ruptured in more than 300 yrs (Philibosian et al., 2011). With an estimated magnitude between 7.2 and 8.1, an earthquake on the southern part of the SAF would cause violent shaking, loss of life, and disruption of infrastructure that may bring much of southern California to a standstill. The Salton Seismic Imaging Project (SSIP; Rose et al., 2013) was undertaken, in part, to understand the structure of the Earth surrounding the SAF in the Coachella Valley. We applied new steep-fault reflection imaging techniques (Bauer et al., 2013) to the SSIP data from fault-crossing seismic profiles to determine the subsurface geometry of the SAF and other faults. These techniques have produced new detailed and interpretable images showing that, unexpectedly, the SAF is nonplanar, dipping moderately northeast at depths below 6-9 km and steeply northeast at shallower depths. Other nearby faults are also imaged in the upper $10 \mathrm{~km}$, appearing to form a flower-like structure largely above the SAF. These new images confirm the basic hypothesis of Fuis et al. (2012) that the SAF dips northeast in this region, but the change in dip at 6-9 $\mathrm{km}$ and possible flower-like structure are new features.

Rupture on a dipping SAF will produce ground shaking that is different from that calculated for the ShakeOut scenario of Jones et al. (2008), which used a fault geometry that is vertical in most places. For a planar approximation to the SAF geometry of this study, we find that shaking is locally amplified by as much as a factor of 2 on the northeast hanging wall and locally deamplified by a similar amount on the southwest footwall.

\section{Geological and Geophysical Setting}

The Salton trough is the northwestward extension of the Gulf of California rift system. The geological, geophysical, 


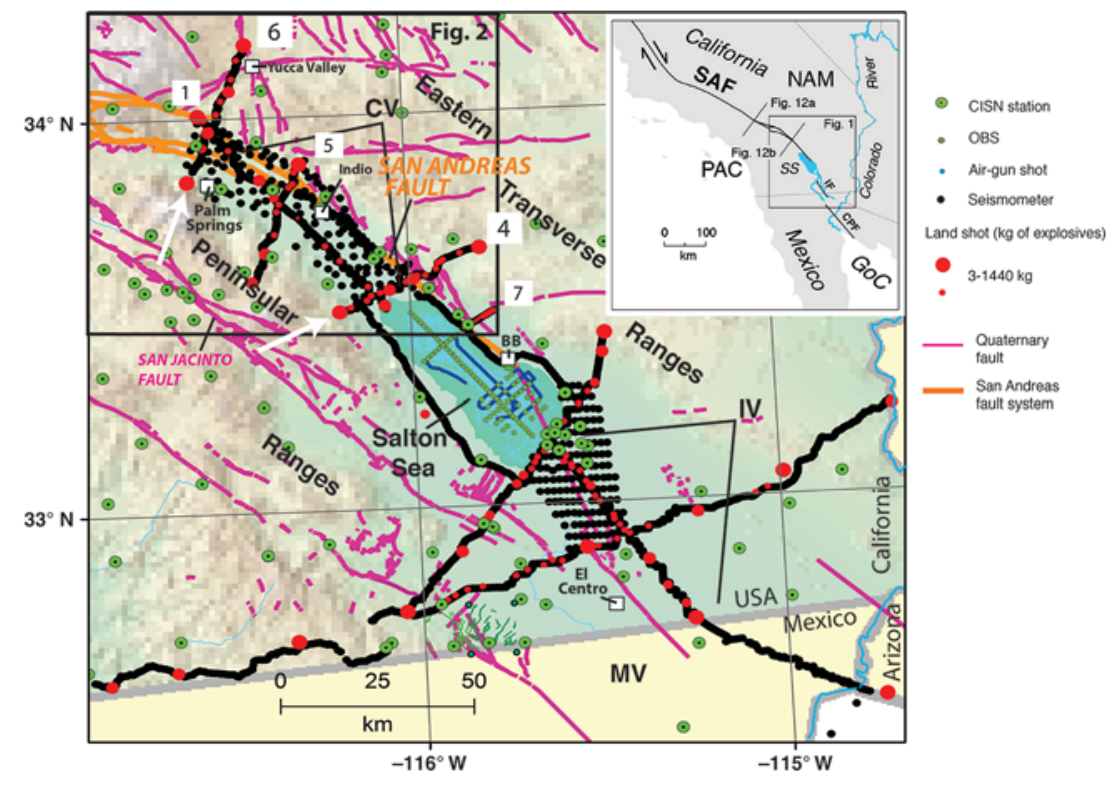

Figure 1. Shaded-relief topographic map of southeastern California showing layout of Salton Seismic Imaging Project (SSIP). BB, Bombay Beach; CV, Coachella Valley; IV, Imperial Valley; MV, Mexicali Valley. White arrows and larger numbers indicate lines 4 and 6. Smaller numbers 1, 5, and 7 are placed at the ends of other lines under analysis by other authors. Faults shown are Quaternary faults from Jennings and Bryant (2010). OBS, ocean-bottom seismometers. (Inset) CPF, Cerro Prieto fault; GoC, Gulf of California; IF, Imperial fault; PAC, Pacific plate; NAM, North American plate; SAF, San Andreas fault; SS, Salton Sea. In blue, we show the Colorado River, which currently empties into the Gulf of California, as well as northward-flowing distributaries that empty into the Salton Sea.

and tectonic setting of the Salton trough is discussed in numerous papers, as summarized in Rose et al. (2013). Subsidence of the Salton trough has been accompanied by a huge influx of sediment from the Colorado River (e.g., Muffler and Doe, 1968). The delta of the Colorado River divides northwardflowing distributaries, that empty into the Salton Sea and former inland lakes (see Philibosian et al., 2011), from southward-flowing distributaries, currently active, that empty into the Gulf of California (Fig. 1, inset map). This delta occupies the southern part of the Salton trough, which includes the Imperial and Mexicali Valleys. Volcanism in the southern Salton trough has been synchronous with subsidence, but volcanic deposits are minor in volume compared to the volume of sediment (e.g., Robinson et al., 1976; Schmitt et al., 2013). This article discusses the northern Salton trough, or Coachella Valley, which contains locally derived material in addition to lake deposits (e.g., McNabb et al., 2017).

Prior seismic imaging studies have been focused chiefly on the Imperial Valley, with minor work in the Coachella Valley (Biehler et al., 1964; Fuis et al., 1984; Parsons and McCarthy, 1996). Analysis of SSIP results for the axial part of the Salton trough from the Mexicali Valley through the Coachella Valley has been performed by Han, Hole, Stock, Fuis, Kell, et al. (2016), and analyses of results for the Imperial Valley have been performed by Persaud et al. (2016) and Han, Hole, Stock, Fuis, Williams, et al. (2016). Major findings for the Imperial Valley are a $2-5 \mathrm{~km}$ thickness of young, unmetamor- phosed sediments, a basement beneath these sediments consisting of young metamorphosed sediments, a mafic layer below that at about $10 \mathrm{~km}$ depth beneath the Salton Sea and Imperial Valley, and a Moho at about 18-20 km depth beneath the Salton Sea and Imperial Valley, deepening in the Mexicali Valley and Coachella Valley.

On the northeast side of the Coachella Valley is the SAF, the northernmost transform fault in a series of right-stepping, dextral transform faults, separated by relatively short rifts extending from the Salton Sea to the mouth of the Gulf of California (Lomnitz et al., 1970; Elders et al., 1972; Lonsdale, 1989; Lizarralde et al., 2007). The SAF initiates at Bombay Beach along the northeast shore of the Salton Sea, extends northwestward to the vicinity of Indio, and then curves to the west in the northern Coachella Valley (Figs. 1 and 2a). The focus of this article is the subsurface geometry of the SAF in the Coachella Valley as revealed by automatic detection and migration of steep reflections on fault-normal profiles (see Figs. 1 and 2a) and joint interpretation with earthquake, gravity, and magnetic studies.

A number of recent geological and geophysical studies support a northeast dip of the SAF in the Coachella Valley. Interferometric Synthetic Aperture Radar (InSAR) studies by Fialko (2006) and InSAR combined with Global Positioning System studies by Lindsey and Fialko (2013) indicate a northeast dip of the SAF averaging $60^{\circ}$ between the Salton Sea and Indio (see Fig. 1). To reproduce observed patterns of vertical deformation and fault strain rates in the Mecca Hills and Indio Hills, on the northeast side of the Coachella Valley, and in the Santa Rosa block of the Peninsular Ranges on the southwest side of the Coachella Valley, Fattaruso et al. (2014) used boundary-element modeling to test various geometries for the SAF and San Jacinto fault (Figs. 1 and 2a). Their results require a northeast dip for the SAF and predict a northeast tilt of the Santa Rosa block; the latter hypothesis is supported by interpretations of geologic and gravity data (Dorsey and Langenheim, 2015).

Studies of the SAF in southern California by Fuis et al. (2012) indicate a propeller shape whereby the SAF dips moderately northeast in the interval from the Salton Sea to the Mojave Desert, steepens to vertical through most of the Mojave Desert, and then dips moderately southwest around the Big Bend where it exits the Transverse Ranges on the northwest. Results in the present study modify the curviplanar shape of the SAF proposed by Fuis et al. (2012) for the Coachella Valley region. The SAF does not appear to be planar in cross section in the Coachella Valley, but rather, it is steeper in the upper crust and less steep in the midcrust. 

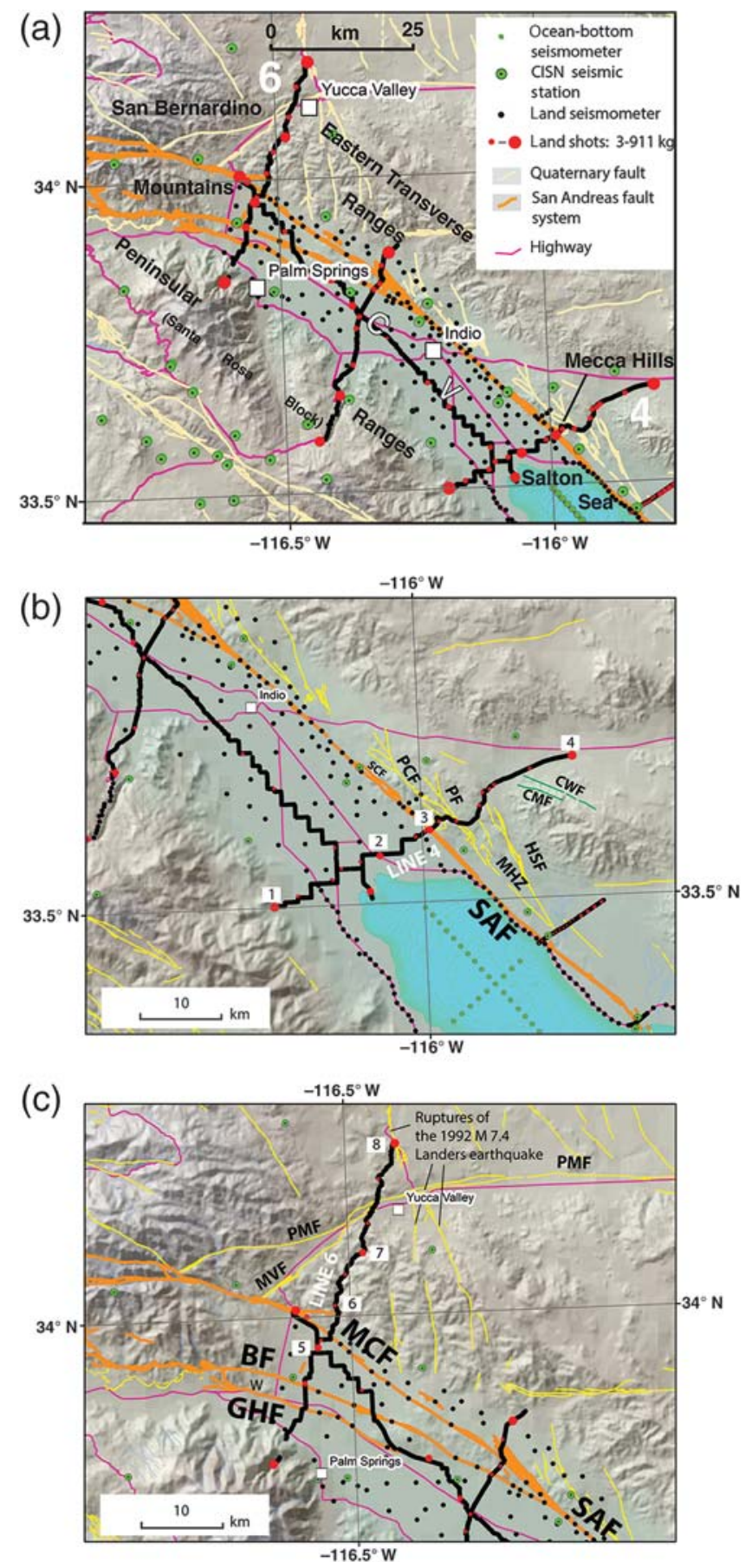

Figure 2. Shaded-relief topographic maps of southeastern California showing northern part of SSIP. (a) Map of Coachella Valley. See Figure 1 for location. CV, Coachella Valley. (b) Map showing area of line 4. Yellow lines, Quaternary faults from Jennings and Bryant (2010); green lines, pre-Quaternary faults from Jennings (1977). Numbers 1-4, shotpoints, gathers for which are shown in Figure 3a. CMF, Chocolate Mountains fault; CWF, Clemens Well fault; HSF, Hidden Springs fault; MHZ, Mecca Hills fault zone, consisting of Painted Canyon (PCF) and Platform (PF) faults north of line 4; SAF, San Andreas fault; SCF, Skeleton Canyon fault. (c) Map showing area of line 6 . Numbers 5-8, shotpoints, gathers for which are shown in Figure 8a. BF, Banning fault; GHF, Garnet Hill fault; MCF, Mission Creek fault; MVF, Morongo Valley fault; PMF, Pinto Mountain fault; W, Whitewater (location).

\section{Experiment Design and Analysis Methods}

\section{Experiment Design}

SSIP acquired data in a series of intersecting seismic refraction and reflection lines and arrays that covered key areas of the Salton trough (Fig. 1; Rose et al., 2013). Seismic sources consisted of buried explosions onshore and air-gun shots in the Salton Sea. Temporary deployments of portable land seismometers and ocean-bottom seismometers (OBS) recorded the seismic sources. SSIP represents much denser data acquisition over a much larger area than prior seismic refraction projects in this area. This article reports results for two fault-perpendicular seismic profiles, one just north of the Salton Sea, line 4 (Figs. 1 and 2b), and one in the northernmost part of the Coachella Valley, line 6 (Figs. 1 and 2c). Analysis of two other fault-perpendicular profiles, lines 5 and 7, are underway, and preliminary results have been reported by Hernandez et al. (2015) and Langenheim et al. (2014), respectively.

\section{Refraction Analysis}

Refraction analysis of lines 4 and 6 consisted of inverting first-arrival travel-time picks for compressional velocity $\left(V_{P}\right)$ using the Hole (1992) and Zelt and Barton (1998) methods. These methods both compute travel times and rays through a densely gridded velocity model using a finite-difference approximation of the Eikonal equation. However, they pose the inversion in different ways that push data misfits into different structures. The Hole (1992) backprojection approach produces a minimum-structure model, whereas the Zelt and Barton (1998) matrix inversion can adjust spatial smoothing to enable additional nonrequired structure to be added to the model. Where nonuniqueness exists, these algorithms can fit the data with different structures (e.g., Hole et al., 2006). Excellent ray coverage, like that along line 4, reduces nonuniqueness, whereas poorer coverage, like that along line 6 , allows a wider range of models to match the data. The 3D velocity model created using the Hole (1992) method is strongly smoothed perpendicular to the profile to produce a $2 \mathrm{D}$ model along a least-squares line fit to the profile. For the Zelt and Barton (1998) method, shot and receiver points are projected onto the least-squares line, thus reducing the 3D problem to a 2D one. See Figure 3 for a comparison of the use of these two inversion methods on the same data set, namely, first-arrival travel-time picks for line 4 . The availability of two independent $V_{P}$ models aids in evaluating the robustness of migrated reflectors from steep interfaces obtained from the method of Bauer et al. (2013). We show here only migration results using velocity models from the Hole (1992) method. Migration results using the method of Zelt and Barton (1998) are similar and are presented along with formal checkerboard tests of that method in Appendices A-C. 
(a)
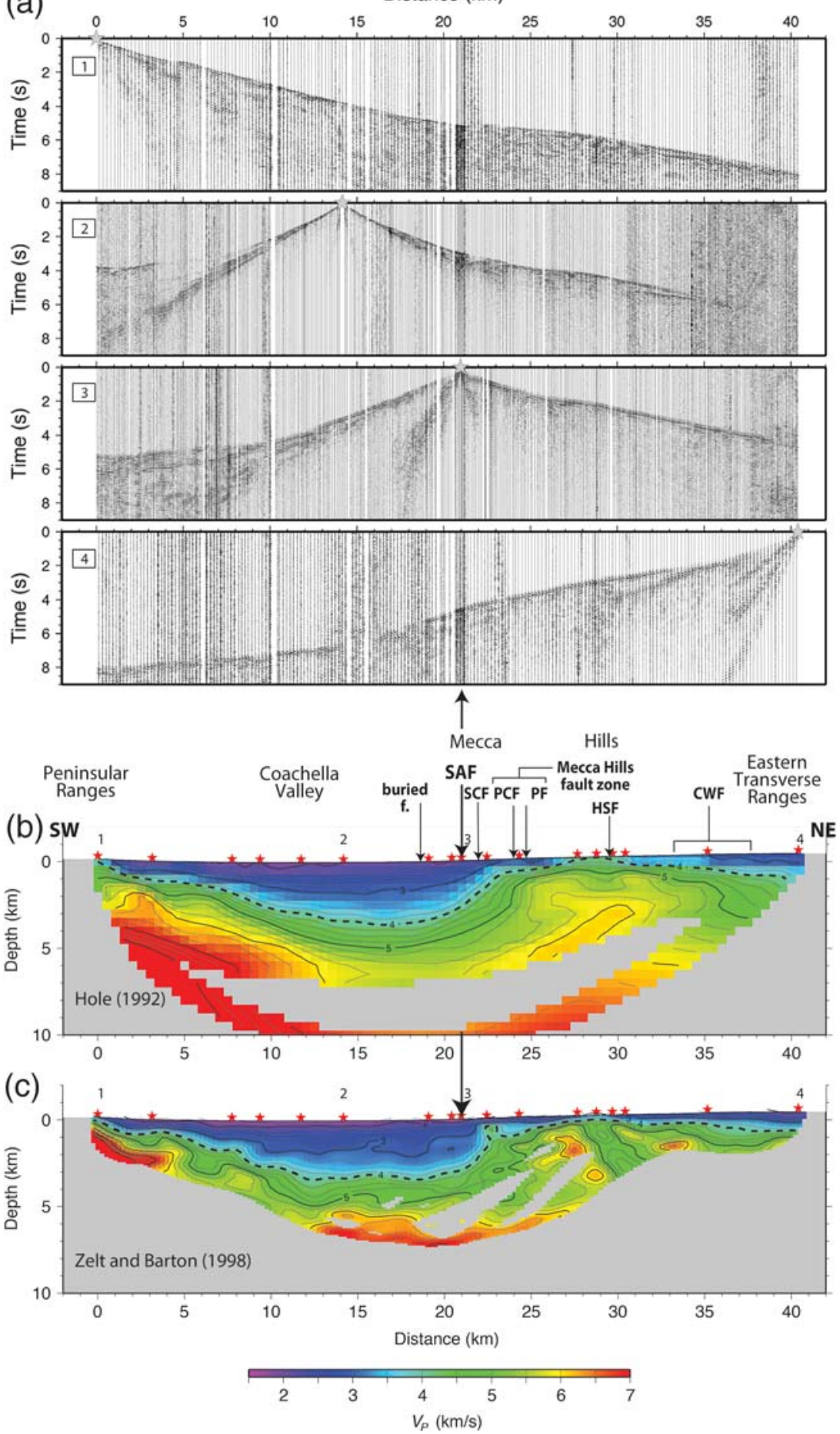

Figure 3. (a) Selected shot gathers from line 4. See Figure $2 b$ for locations of shotpoints $1-4$. Both models plotted below the shot gathers $(b, c)$ are constructed from firstarrival picks from these and 13 other shot gathers. (b,c) Line 4 tomographic models using the methods of (b) Hole (1992) and (c) Zelt and Barton (1998). Red stars indicate shotpoints. Velocity contours are lightweight every $0.25 \mathrm{~km} / \mathrm{s}$ and heavy every $1 \mathrm{~km} / \mathrm{s}$. Black dashed line is $4 \mathrm{~km} / \mathrm{s}$ contour, which represents in most places minimum depth to basement. Because both models were derived from the same first-arrival picks, model similarities and differences indicate areas of better and poorer resolution, respectively. CWF, Clemens Well fault (buried); HSF, Hidden Springs fault; PCF, Painted Canyon fault; PF, Platform fault; SAF, San Andreas fault; SCF, Skeleton Canyon fault.

\section{Reflection Analysis}

Reflection analysis consisted of automatic detection of coherent secondary arrivals in individual record sections followed by prestack migration of these detected phases (Bauer et al., 2013). Preprocessing of data included trace mean removal, band-pass filtering $(10-20 \mathrm{~Hz})$, deconvolution, and automatic gain control. The work flow applied after the preprocessing is illustrated by a synthetic example in Figure 4. Shot-gathered data are analyzed in the time domain using a moving window (Fig. 4a). Only windowed samples are considered. A point $i$ is chosen at the center of this window, in which a semblance analysis is carried out (Fig. 4b). Local slant stacks over neighboring traces are calculated for a given range of slowness values. The local slant stack with the highest semblance (coherency) value defines the local slowness of the wavefield at the analyzed sample $i$. Only samples with a slowness reverse to the first-arrival phase (reverse moveout) are considered in this study, because reflections from steep faults can be detected by such a moveout (e.g., Bauer et al., 2013). A line segment is drawn in the time domain with the corresponding dip and centered at the analyzed sample (Fig. 4b). A prestack migration is then used to map the line segment from the time domain into the depth domain, based on a given velocity model (Fig. 4c). A ray is shot from the receiver downward. The initial shooting direction of the ray is defined by the given velocity at the receiver and the slowness $\left(p_{i}\right)$ derived from the semblance analysis. The line is migrated to the location where the ray crosses the isochrone. The isochrone represents subsurface locations of equal reflection time $t_{i}$ for a given coherent sample $i$. Finally, the line segment is drawn at the migration point with the local dip in the depth domain. More details on the prestack line migration are described in Bauer et al. (2013). Applications of the method and more practical aspects can be found in Ryberg et al. (2015) and Feld et al. (2017).

\section{Potential-Field Analysis}

We modeled isostatic gravity and aeromagnetic data to isolate upper-tomidcrustal density and magnetic-property 


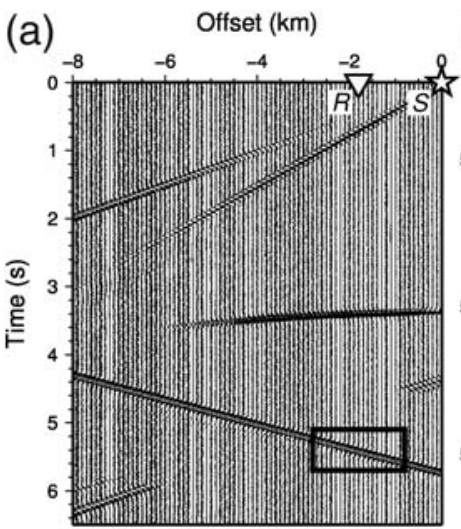

(b)
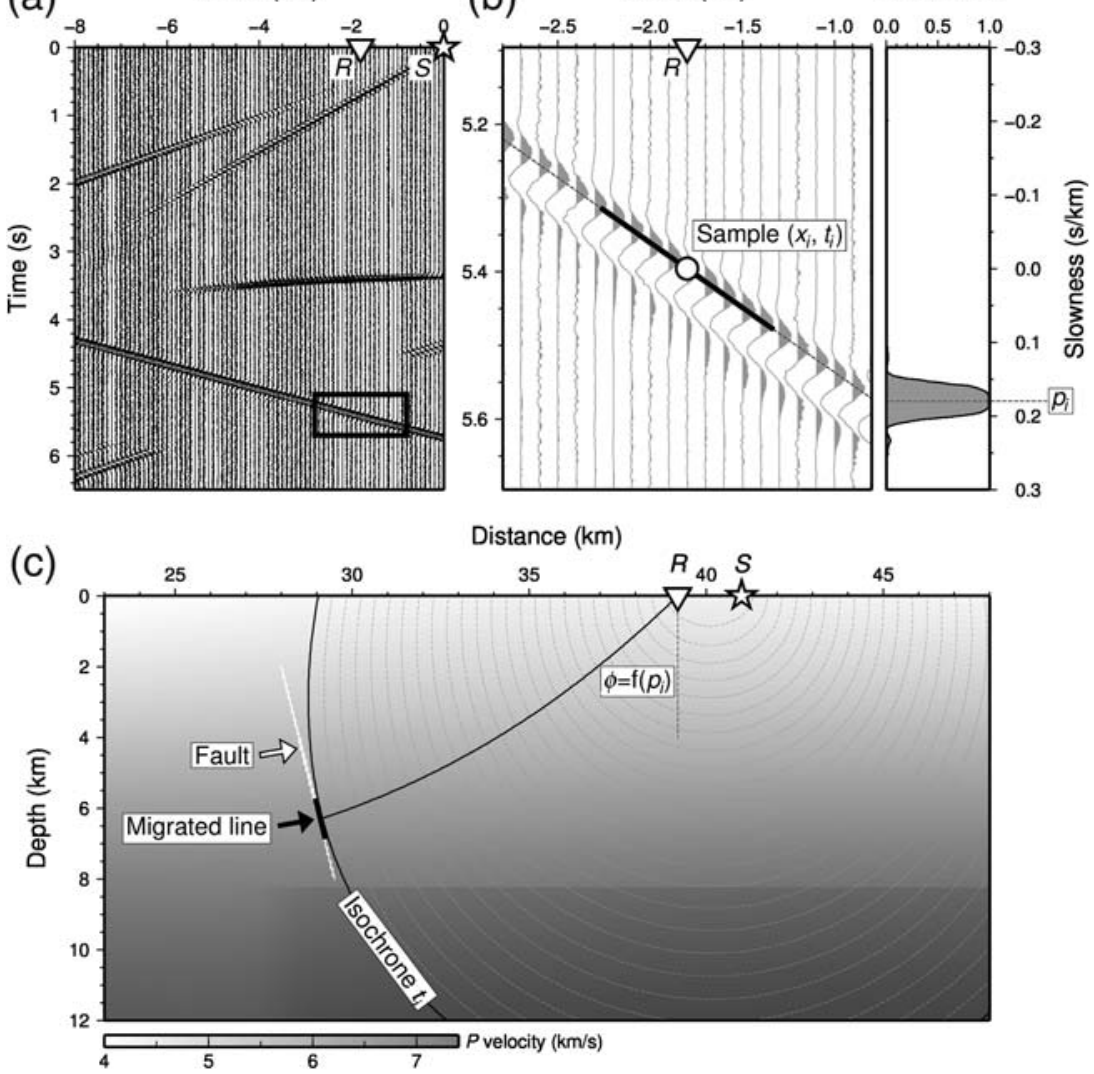

Figure 4. (a) Synthetic data illustrating the prestack line-migration method of Bauer et al. (2013). R, receiver; S, shotpoint. Black rectangle is moving window in which maximum semblance is calculated. (b) Enlargement of moving window of (a) in which semblance analysis is carried out. Small circle is the point of calculation centered at offset $x_{i}$ and time $t_{i}$ for receiver R. The line segment (bold black line) corresponds to the slowness $p_{i}$ with the maximum semblance (coherency) for this window. (c) Prestack migration to map the line segment from time to depth domain. Raytracing starts at the receiver $\mathrm{R}$. The initial ray direction $\phi$ is a function of local slowness $p_{i}$ derived by the semblance analysis. The migration point is determined where the ray crosses the isochrone for reflection time $t_{i}$. Note that the white line tangent to isochrone $t_{i}$ is the lowvelocity fault zone causing the reflection.

variations on lines 4 and 6 , using a method described by Simpson et al. (1986) and Langenheim and Hauksson (2001). For this modeling, we used a 2.5 dimensional simultaneous gravity and magnetic forward-modeling program. The program requires an initial estimate of model parameters (depth, shape, magnetization, and density of suspected sources) and then varies selected parameters in an attempt to reduce the error between the observed and calculated potential fields. The initial model estimate is based on mapped surface-geologic relationships and physical-property information. The amplitude of an anomaly is not the only attribute to match; its gradients and inflections are critical parameters that provide important information on the depth to the top of a source and its shape. Although interpretation of potentialfield data yields nonunique solutions, the final models are based on both gravity and magnetic data and numerous iterations. The models have been extensively tested to ensure that they are geologically reasonable with minimum struc- tural complexities. The synthesis of the potential-field data and independent constraints described below leads to a family of similar models, regardless of the starting model, with characteristics that support our major conclusions on the subsurface geology, in particular with regard to the dip of the SAF. The potential-field model(s) are quite similar to those presented by Langenheim et al. (2012) that were created prior to reflection analysis.

\section{Earthquake Display}

For our display of earthquakes, we used hypocenters from the Hauksson et al. (2012) catalog, which spans the period of time of 1981-2011, and the focal mechanisms from the Yang et al. (2012) catalog for these same hypocenters. We display different subsets of the Yang et al. (2012) focal mechanisms for the less seismically active line 4 region than for the more seismically active line 6 region. For line 4, we chose the three highest-quality categories of focal mechanisms (A, B, and C), excluding the lowest-quality category (D), and we display events of all magnitudes for which focal mechanisms were calculated; this yields 50 events ranging in magnitude from 0.9 to 2.9. For line 6, we chose the two highest-quality categories of focal mechanisms (A, B), and we display all events magnitude 2.0 and greater; this yields 832 events ranging in magnitude from 2.0 to 5.7, although many events overlie one another. We have projected focal mechanisms onto our profiles, which are least-squares lines fit to receiver and shotpoint locations. Our presentation of focal mechanisms is only for visual comparison with our inferred fault-plane geometry.

\section{Results}

\section{SSIP Line 4}

Geologic and Tomographic Framework for Line 4. Line 4 extends northeast across the Coachella Valley from the Peninsular Ranges into the eastern Transverse Ranges just north of the Salton Sea (Fig. 2b). First-arrival travel times for line 4 were inverted for seismic compressional velocity $\left(V_{P}\right)$, using the methods of Hole (1992) (Fig. 3b) and of Zelt and Barton (1998) (Fig. 3c). Lateral travel-time variations giving rise to these models are shown in the record sections plotted above (Fig. 3a). Because both models were derived from the same first-arrival travel-time picks, model similarities and differences indicate areas of better and poorer resolution, 
respectively. Formal resolution for the model of Figure $3 \mathrm{c}$ (from the Zelt and Barton, 1998, method) is displayed in checkerboard tests in Appendix A, in which one can observe the sizes and locations of features that are well resolved.

Shotpoints at 0 and $28.5 \mathrm{~km}$ are in outcrops of basement rocks (granitic rocks and Orocopia Schist, respectively), whereas all other shotpoints are in Cenozoic clastic sedimentary rocks. Surface $V_{P}$ at the two basement shotpoints is somewhat less than $4 \mathrm{~km} / \mathrm{s}$. Throughout the rest of the model, the top of basement may, thus, be at or below the $4 \mathrm{~km} / \mathrm{s}$ contour (dashed black line, Fig. 3b,c). Sedimentary basin depth reaches $4 \mathrm{~km}$ southwest of the SAF and is asymmetric, with a relatively abrupt decrease near the SAF.

Basement southwest of the SAF is likely to be Mesozoic batholithic rocks of the Peninsular Ranges, as described most recently by Morton et al. (2014). Analysis of line 1, along the approximate axis of the Coachella Valley (Fig. 1), by Han, Hole, Stock, Fuis, Kell, et al. (2016), indicates that basement velocity reaches $6.2 \mathrm{~km} / \mathrm{s}$ at depths ranging between 3 and $6 \mathrm{~km}$, depending on how close line 1 is to Peninsular Ranges outcrops to the west. Northeast of the SAF, crystalline rocks are exposed in canyons in the Mecca Hills (Sylvester and Smith, 1976; McNabb et al., 2017) and include Precambrian rocks and Mesozoic Orocopia Schist. East of the Mecca Hills, basement rocks also include Mesozoic intrusive rocks exposed off line. The Mecca Hills basement is the equivalent of basement exposed in the San Gabriel Mountains, displaced along the SAF by $\sim 160 \mathrm{~km}$ (Powell, 1993). Overlying the basement are Cenozoic sedimentary rocks ranging in age from Upper Miocene or Pliocene to Holocene (Sylvester and Smith, 1976; McNabb et al., 2017). These rocks are folded and offset by faults in the Mecca Hills (Fig. 2b). The faults, in addition to the SAF, include the Skeleton Canyon, Painted Canyon, Platform, and Hidden Springs faults (see Sylvester and Smith, 1976; Jennings and Bryant, 2010; McNabb et al., 2017). The Painted Canyon and Platform faults combine into a fault zone known as the Mecca Hills fault zone south of line 4. The northernmost extent of the Hidden Springs fault occurs at line 4. Farther northeast, the Clemens Well fault, interpreted as an ancestral SAF by Powell (1993), is buried beneath line 4. Most faults strike perpendicular to line 4, making the bend in the line $(24-28 \mathrm{~km})$ of less concern in refraction and reflection analysis than if the geology were significantly $3 \mathrm{D}$.

Reverse-Moveout Reflections, Earthquakes, and PotentialField Modeling on Line 4. An example of the detection and migration of reverse-moveout reflections from steep structures is shown for a shot gather at the northeast end of line 4 (Fig. 5; see also Fig. 3a, shotpoint 4). This shotpoint reveals the major packages of reflections seen on line 4 , and adding reflections from other shotpoints enhances this picture. A prominent package of migrated reverse-moveout phases is observed dipping $50^{\circ} \mathrm{NE}$ at depths of 7-11 km and model ranges of 23-27 km beneath the Mecca Hills (Fig. 6a,b, reflections A; all dips stated herein are apparent dips). Migration was performed using the velocity model derived using

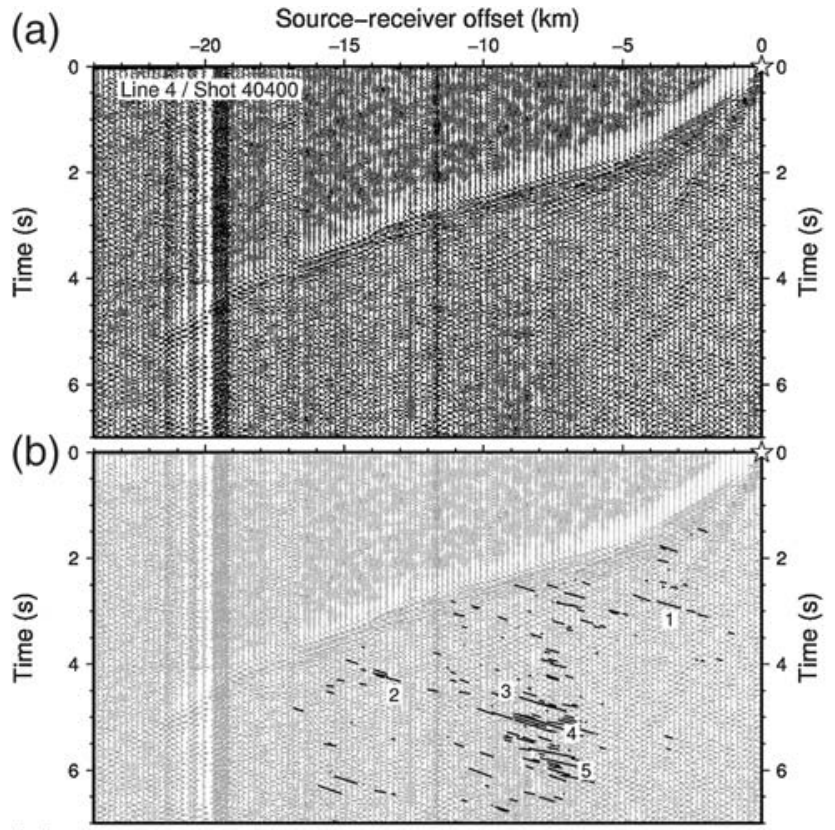

(c)
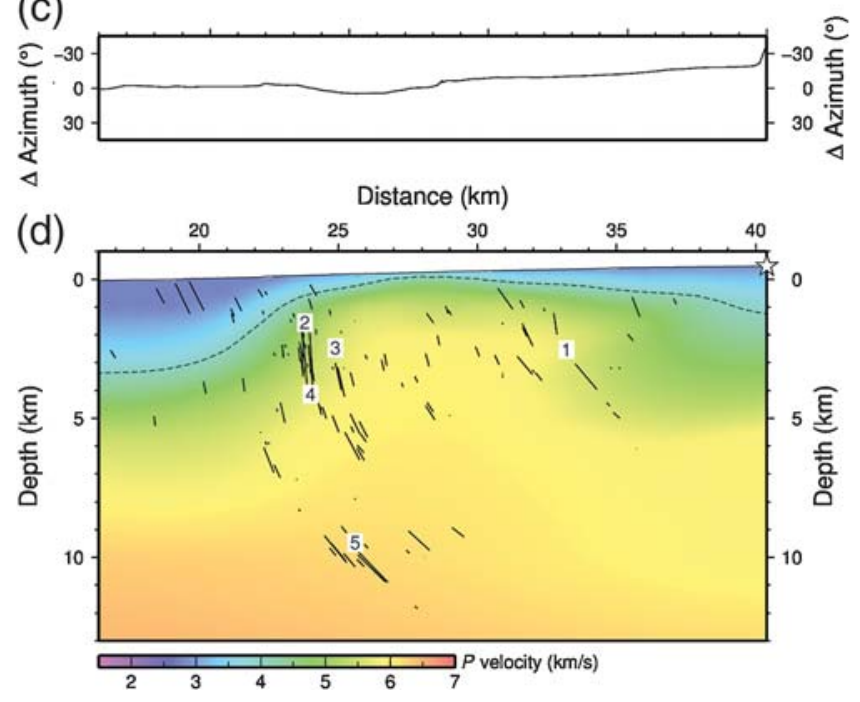

Figure 5. (a) Shot-gathered data for shot 40400 (see Rose et al., 2013) after preprocessing (same shot gather as gather 4 in Fig. 3a). (b) Automatic detection of coherent line segments that show a reverse moveout and migrate to steeply dipping structures. Note that the reverse-moveout reflections are not always easily evident to the eye because they cross stronger direct and forward-scattered energy and must be detected (automatically) using a coherency criterion. A migration criterion also must be met; that is, these must migrate to have dips within a certain range and fall within the depth section shown in (d). (c) Difference between azimuth from shot to receiver and profile azimuth. (d) Depth migration of the line segments from (b). Labeling allows identification of specific line-segment packages (1-5), both in time and depth domain.

the method of Hole (1992) (Fig. 3b); see Appendix B for similar phases migrated in the velocity model derived using the method of Zelt and Barton (1998). These phases align approximately with relocated microearthquakes in this area (Fig. 6c; Lin et al., 2007; Hauksson et al., 2012; Yang et al., 2012). Centered at $6 \mathrm{~km}$ depth and model range $22.5 \mathrm{~km}$ is a 

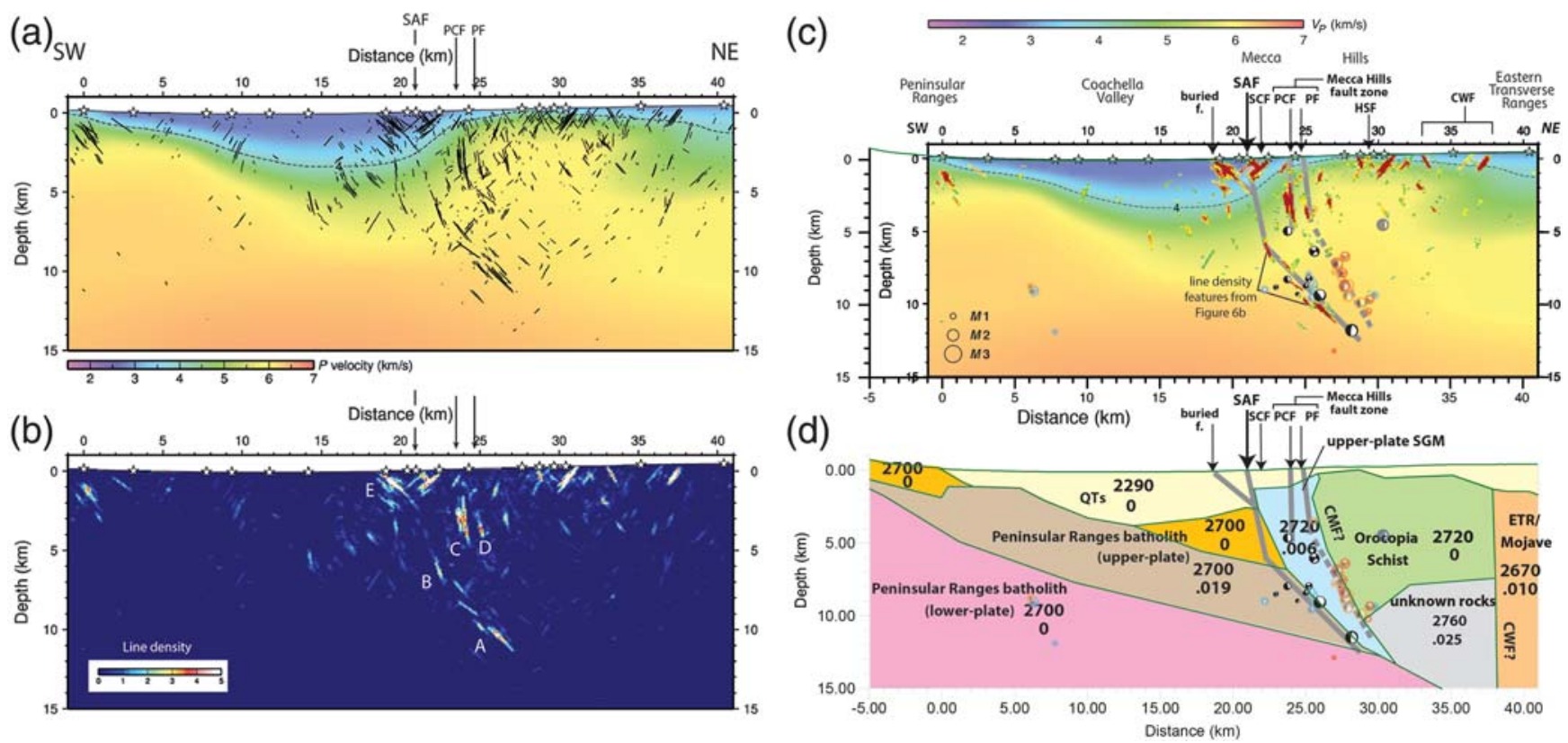

Figure 6. (a) Line-drawings of reverse-moveout reflections from line 4 migrated in the velocity model derived using the inversion algorithm of Hole (1992), supplemented by the Southern California Earthquake Center (SCEC) Community Velocity Model (CVM) at depths below SSIP ray coverage (see Fig. 3b). White stars, shotpoints. (b) Line-drawing density diagram of reflections shown in (a). Line density is the number of migrated line segments in $100 \mathrm{~m} \times 100 \mathrm{~m}$ grid cells weighted by their underlying waveform coherencies. See the ReverseMoveout Reflections, Earthquakes, and Potential-Field Modeling on Line 4 section for description of labels A through E. (c) Velocity model for line 4 with line-density features from (b) (using slightly different colors for line density), earthquakes (focal mechanisms), and interpreted faults (heavy gray lines). M, magnitude. Far-hemisphere focal mechanisms (fm) from Yang et al. (2012) using hypocenters of Hauksson et al. (2012): black, fm within $2 \mathrm{~km}$ of line 4; dim gray and blue, fm from 2 to $10 \mathrm{~km}$ northwest of line 4; dim orange and red, fm from 2 to $10 \mathrm{~km}$ southeast of line 4. Focal mechanisms are from the period 1981-2011. The focal mechanism solutions displayed are from the three highestquality categories (A, B, C) of Yang et al. (2012). CWF, Clemens Well fault (buried); PCF, Painted Canyon fault; PF, Platform fault; SAF, San Andreas fault; SCF, Skeleton Canyon fault. (d) Joint model of gravity and magnetic data along line 4. Interpreted faults (gray) and fm are repeated from (c). Density ( $\mathrm{kg} / \mathrm{m}^{3}$; top numbers); magnetic susceptibility $\left(10^{-3} \mathrm{SI}\right.$; bottom numbers). QTs, Quaternary-Tertiary sediments; CMF?, Chocolate Mountains fault? (buried, overturned?); ETR, eastern Transverse Ranges rocks; and SGM, San Gabriel Mountains rocks (see Powell, 1993). For data fits, see Figure 7. Figure 6c and 6d shows that the deep part of the SAF dips moderately northeast, with a flowerlike structure, consisting of steeply dipping faults, developed above this zone (including the upper part of the SAF itself), the Painted Canyon and Platform faults, and possibly a buried fault at $18.5 \mathrm{~km}$ range. The upper, steeply dipping part of the SAF (above $\sim 6 \mathrm{~km}$ depth) is neither imaged by reflections or earthquakes. Its connection to the deeper, moderately dipping fault is inferred from the reflection pattern.

short package of reflections (B in Fig. 6b) that diverges from the moderate dips below and projects upward toward the surface trace of the SAF. Steeply dipping packages of migrated reflections are also seen centered between 2.5 and $3.5 \mathrm{~km}$ depth between model ranges 24 and $25 \mathrm{~km}$ (Fig. 6a,b, reflections $\mathrm{C}$ and $\mathrm{D}$ ). These packages project approximately to surface traces of the Painted Canyon and Platform faults. Other prominent packages are seen in the upper couple of kilometers, at $\sim 0,18.5,21,22.5,31$, and $37.5 \mathrm{~km}$, the most prominent of which is the one at $18.5 \mathrm{~km}$ (Fig. 6a,b, reflection E). This latter reflection, located southwest of the SAF, does not project upward to a mapped fault. If it is a buried fault, it may or may not be related to faults proposed in a similar structural position with respect to the SAF in the region southeast of the Mecca Hills by Markowski (2016), Janecke et al. (2016), and S. Janecke (written comm., 2017) from surface geologic mapping, or Sahakian et al. (2016) from air-gun and sparker seismic imaging in the Salton Sea.

The faults interpreted from our data for the Painted Canyon and Platform faults may project downward to junctions with the interpreted SAF at a depth of about $10 \mathrm{~km}$ to form a flower-like structure above the SAF. Alternatively, the interpreted Platform fault may project downward to join the alignment of hypocenters along the Chocolate Mountains fault (Fig. 6d).

Joint modeling of isostatic gravity and aeromagnetic anomalies along line 4 uses the surface geology as a critical constraint and was developed independently of the reflection study, as was discussed above (Figs. 6d and 7). Sedimentary rocks were chosen to have a density contrast with basement of $\sim 400 \mathrm{~kg} / \mathrm{m}^{3}$, based on other modeling studies in southern California (e.g., Mabey, 1960; Dorsey and Langenheim, 2015). This contrast is consistent with the average density contrast predicted by the velocity structure within the basin using the relationship of Gardner et al. (1974) to convert velocity to density. Densities and magnetic susceptibilities assigned to basement rocks are guided by measurements of hand samples (Anderson et al., 2004; Langenheim and Powell, 2009). The Orocopia Schist (lower plate of the Chocolate Mountains fault, interpreted to be overturned in 

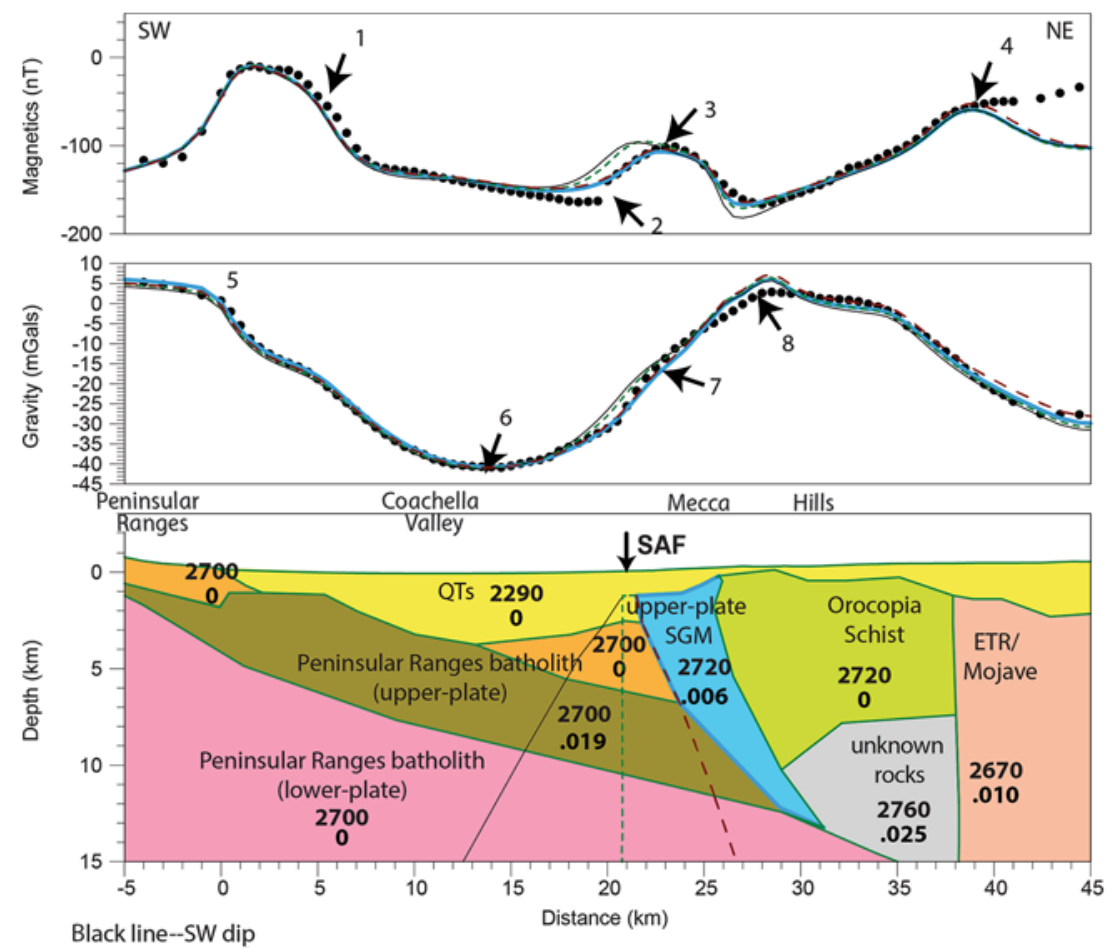

Green short-dashed line--vertical dip

Maroon dashed line--straight NE dip

Blue line--two-part NE dip

Figure 7. Joint model of gravity and magnetic data along line 4. In data panels, dots are gridded values from observations, and lines are calculated values from various alternate models (see line legend at lower left). Densities ( $\mathrm{kg} / \mathrm{m}^{3}$; top numbers); magnetic susceptibilities ( $10^{-3} \mathrm{SI}$; bottom numbers). See the Reverse-Moveout Reflections, Earthquakes, and Potential-Field Modeling on Line 4 section for description of labels 1-8.

Fig. 6d) and most of the eastern Peninsular Ranges batholith do not produce measurable magnetic anomalies, in contrast to rocks in the upper plate of the Chocolate Mountains fault (basement of San Gabriel Mountains affinity) and rocks in the eastern Transverse Ranges (Langenheim et al., 2005).

The gravity model indicates that the sedimentary fill reaches a thickness of nearly $4 \mathrm{~km}$ under the central Coachella Valley to account for the 40-50 mGal gravity low in Coachella Valley (Fig. 7, feature 6) relative to measurements made on basement (Fig. 7, features 5 and 8). More pertinent to the dip of the SAF is matching the gravity gradient (7) and magnetic high (3) that bounds the northeast side of Coachella Valley. The gravity gradient (7) suggests a steep $1 \mathrm{~km}$ step that projects up to the surface trace of the SAF, whereas the position of the magnetic high (3) and its sharp southwest gradient (2) indicate a steep, northeast-dipping southwest edge of the magnetic body to about $6 \mathrm{~km}$ depth. A vertical or southwest-dipping SAF clearly does not fit the data (see Fig. 7, alternate models). The difference in fit between a straight northeast dip and a two-part northeast dip is subtle and not statistically significant, but the latter configuration provides a slightly steeper southwest edge to the magnetic high that matches the observed gradient (2) slightly better.

The source of feature 3 (Fig. 7) is attributed to Precambrian metamorphic and granitic rocks that crop out in canyons of the Mecca Hills northeast of the SAF (Sylvester and Smith, 1976; McNabb et al., 2017). These rocks occur in the upper plate of the Chocolate Mountains fault, which, in our model, is interpreted to be overturned. The steep interpreted boundary between nonmagnetic Orocopia Schist and these magnetic Precambrian rocks appears to coincide with microearthquakes southeast of line 4 (Fig. 6d, orange and red focal mechanisms) and suggests that the Chocolate Mountains fault may be reactivated there and may possibly project to the surface as the present-day Platform fault. If so, this structure may be part of the flower-like structure we interpret above the dipping SAF, and its intersection with the SAF projects to a depth of about $13 \mathrm{~km}$.

The gentle magnetic gradient southwest of feature 4 (Fig. 7) indicates the presence of magnetic rocks which are not exposed along this stretch of the profile. Instead, nonmagnetic Orocopia Schist is exposed at model coordinate $28 \mathrm{~km}$. If magnetic upper-plate rocks were concealed at shallow depth beneath the sedimentary cover along the profile southwest of (4), the presence of Orocopia Schist at model coordinate $28 \mathrm{~km}$ would produce a sharp magnetic low, which is not observed. Thus, magnetic rocks of unknown affinity must underlie line 4 at greater depth, southwest of (4) (Fig. 7, unknown rocks).

The gentle magnetic gradient southwest of (4) is interrupted by a small step at model coordinate $38 \mathrm{~km}$, which we interpret as the buried contact between Orocopia Schist basement to the southwest and magnetic rocks associated with eastern Transverse Ranges basement to the northeast (Fig. 7). This contact approximately follows the trend of the Clemens Well fault (Jennings, 1977), considered to be an ancestral SAF by Powell (1993). However, the northwest projection of the Clemens Well fault from its exposure (Fig. 2b) to line 4 occurs at model range $\sim 33 \mathrm{~km}$, which is $\sim 5 \mathrm{~km}$ southwest of the modeled magnetic boundary (model range $38 \mathrm{~km}$ ).

Near the southwest end of line 4, a pronounced magnetic high (1) and absence of an accompanying low (of similar but reversed shape) to the northeast indicates that magnetic rocks extend beneath the Coachella Valley. This magnetic layer may correlate with outcrops immediately north of line 4 in the Peninsular Ranges that include crystalline magnetic rock packages (Langenheim et al., 2005) underlain by detachment faults (Matti et al., 1983; Erskine and Wenk, 1985; White, 2006; Morton et al., 2014). Note again that most of the eastern Peninsular Ranges batholith is nonmagnetic (Langenheim et al., 2005). 
(a)
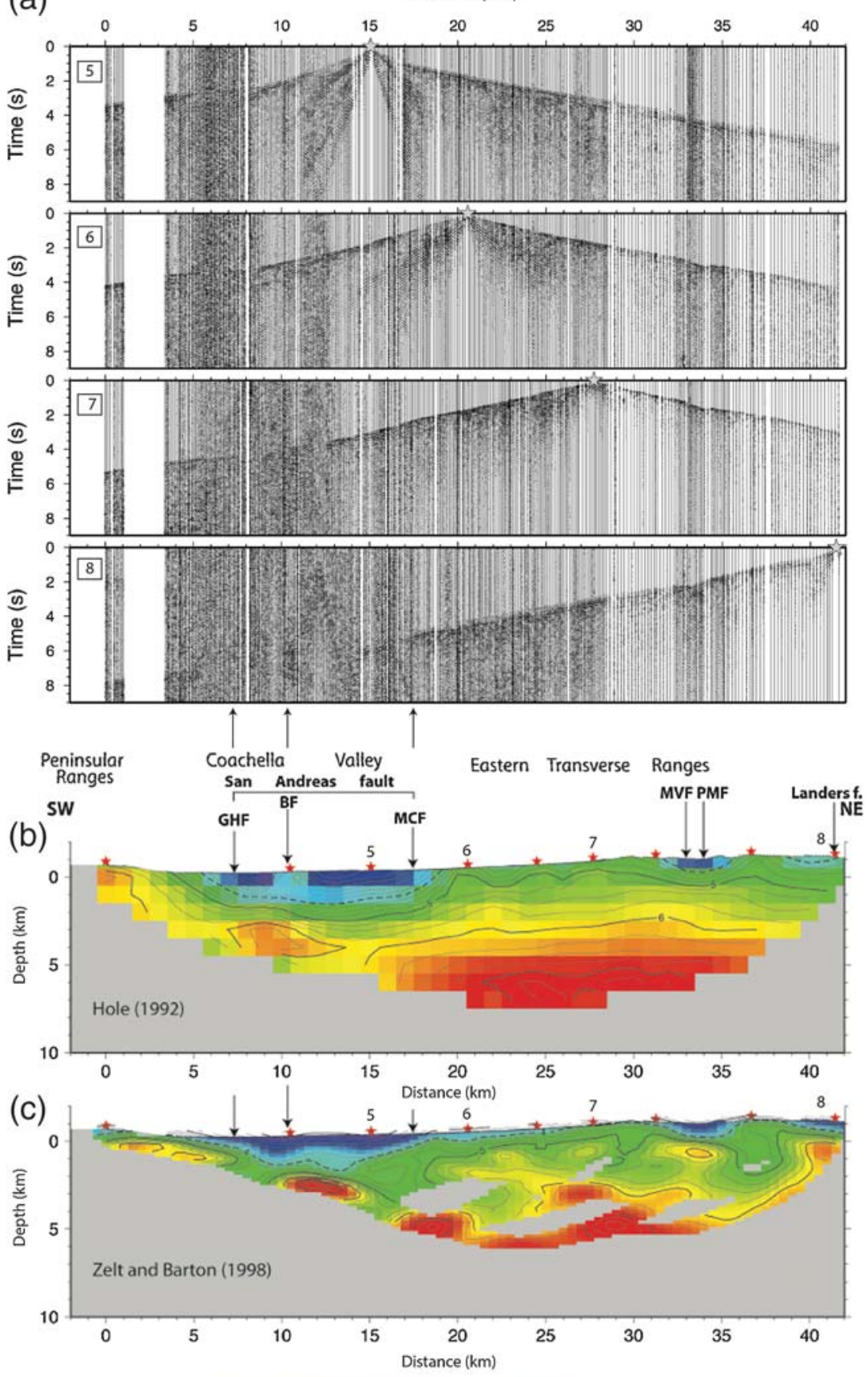

$\begin{array}{llllllllllll}1.5 & 2.0 & 2.5 & 3.0 & 3.5 & 4.0 & 4.5 & 5.0 & 5.5 & 6.0 & 6.5 & 7.0\end{array}$

$V_{p}(\mathrm{~km} / \mathrm{s})$

Figure 8. (a) Selected shot gathers from line 6. See Figure $2 \mathrm{c}$ for locations of shotpoints $5-8$. Both models plotted below the shot gathers $(b, c)$ are constructed from firstarrival picks from these and five other shot gathers. (b,c) Line 6 tomographic models using the method of (b) Hole (1992) and (c) Zelt and Barton (1998). Red stars, shotpoints. Velocity contours are lightweight every $0.25 \mathrm{~km} / \mathrm{s}$ and heavy every $1 \mathrm{~km} / \mathrm{s}$. Black dashed line is a $4 \mathrm{~km} / \mathrm{s}$ contour, which represents in most places minimum depth to basement. Because both models were derived from the same first-arrival picks, model similarities and differences indicate areas of better and poorer resolution, respectively. BF, Banning fault; GHF, Garnet Hill fault; MCF, Mission Creek fault; MVF, Morongo Valley fault; PMF, Pinto Mountain fault.

\section{SSIP Line 6}

Geologic and Tomographic Framework for Line 6. Line 6 extends north from the Peninsular Ranges, across the northern Coachella Valley (4-17 km in Fig. 8), and into the eastern Transverse Ranges and Mojave Desert (Fig. 2c). Shotpoints at 0 and $20-41 \mathrm{~km}$ are in granitic or gneissic rocks, and those within Coachella Valley are in Cenozoic clastic sedimentary rocks. Basement depths beneath the sedimentary rocks are constrained by only two shotpoints (at 10.5 and $15 \mathrm{~km}$ model coordinates) and are estimated to be $2-3 \mathrm{~km}$ in the Coachella Valley. Faults crossed by the profile include the three branches of the SAF (Garnet Hill, Banning, and Mission Creek faults) and the Morongo Valley and Pinto Mountain faults (Figs. 2c and 8). The Garnet Hill and Banning faults are considered to be the most active strands of the SAF (Gold et al., 2015), and the Mission Creek fault in this location, although depicted as currently inactive by Jennings and Bryant (2010), apparently has had some Holocene and late Pleistocene activity (Fumal et al., 2002; Blisniuk et al., 2012; Gold et al., 2015).

Basement beneath the northern Coachella Valley is not clearly interpretable, except by projection of basement geology from the San Bernardino Mountains on the northwest beneath the Cenozoic sedimentary rocks. Basement exposed on the northwest is San-Gabriel-Mountains-type rocks (Allen, 1957; Matti et al., 1992; Langenheim et al., 2005).

Reverse-Moveout Reflections, Earthquakes, and Potential-Field Modeling on Line 6. Steeply dipping reflections are obtained as for line 4 (Figs. 9 and 10; see also Appendix C). A curving group of dipping reflections (Fig. 10a,b, features a, b) in the 3-13 km depth range and $10-15 \mathrm{~km}$ model range are prominent among these. A second prominent reflection package (Fig. 10a,b, feature f) extends from approximately the surface to more than $6 \mathrm{~km}$ depth at model 33-34 $\mathrm{km}$ range. Other reflections include a diffuse package (Fig. 10a,b, feature c) extending from 2 to $7 \mathrm{~km}$ depth at $13-15 \mathrm{~km}$ model range, a strong southwest-dipping reflection at 2$4 \mathrm{~km}$ depth (Fig. 10a,b, feature d), cen- 


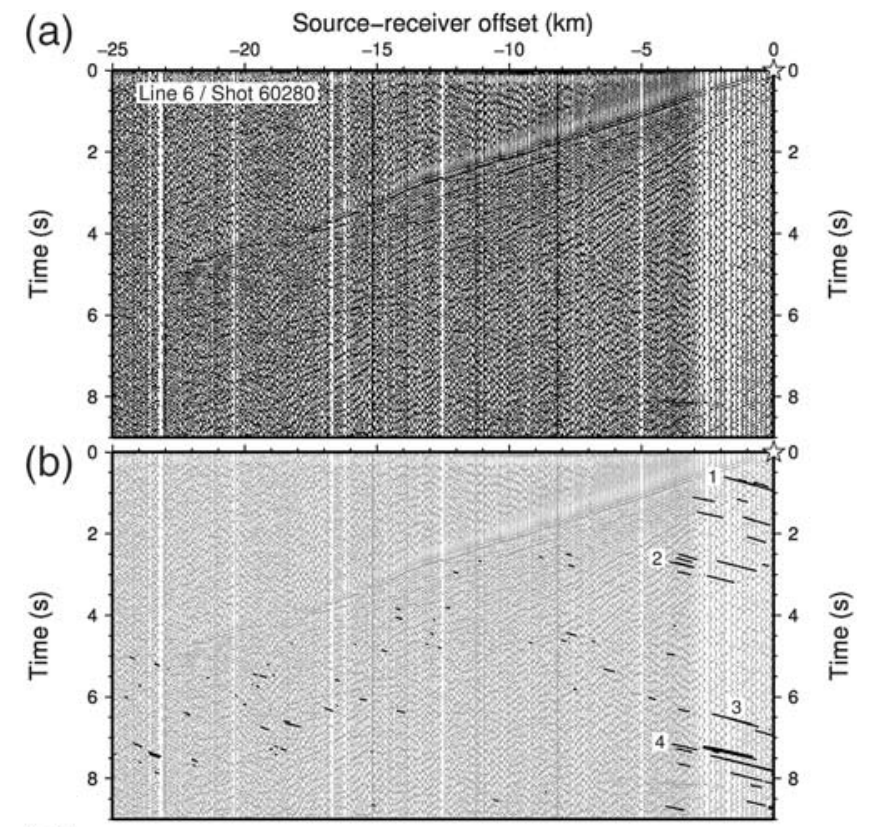

(c)
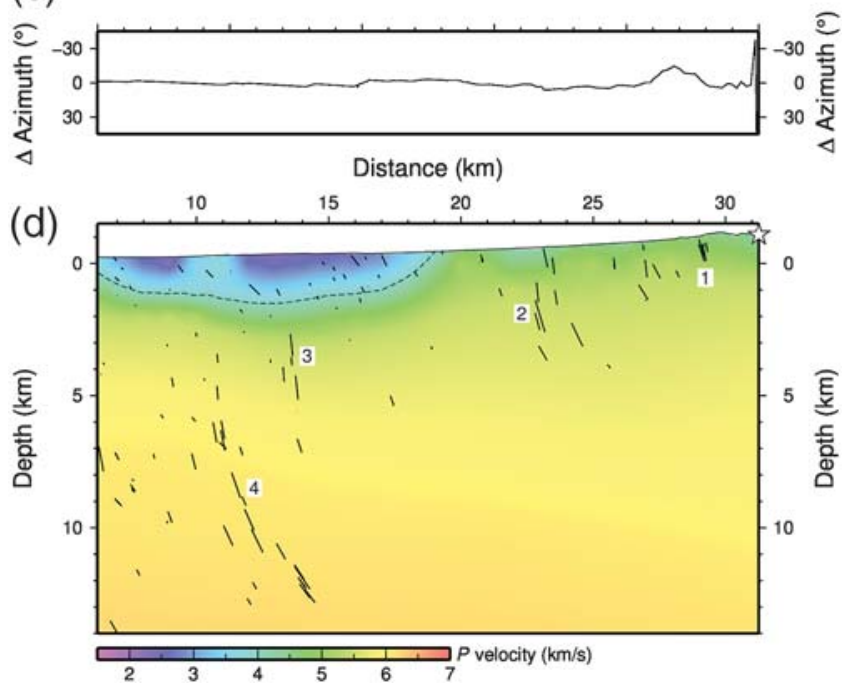

Figure 9. (a) Shot-gathered data for shot 60280 (see Rose et al., 2013) after preprocessing. (b) Automatic detection of coherent line segments which show a reverse moveout and migrate to steeply dipping structures. Note that the reverse-moveout reflections are not always easily evident to the eye because they cross stronger direct and forward-scattered energy and must be detected (automatically) by a coherency criterion. A migration criterion also must be met; that is, these must migrate to have dips within a certain range and fall within the depth section shown in (d). (c) Difference between azimuth from shot to receiver and profile azimuth. (d) Depth migration of line segments in (b). Labeling allows identification of specific line segment packages (1-4), both in time and depth domain.

tered at $20 \mathrm{~km}$ model range, and a package that shows up somewhat differently in the Hole (1992) and Zelt and Barton (1998) models at variable depths and model ranges (Figs. 10b and $\mathrm{C} 1$, feature e). Other reflection trends are seen in the near-surface region (0-2 km depth), including one seen only in the migration model of Zelt and Barton (1998) (Fig. C1, feature g). This latter reflection is not considered robust.
The curving group of reflections $(a, b)$ in Figure $10 b$ spans the depth interval of the relocated mainshock and aftershocks of the 1986 North Palm Springs earthquake (Hauksson et al., 2012). The mainshock ( $M_{\mathrm{w}} 6.1$, Nicholson, 1996) occurred $\sim 8 \mathrm{~km}$ northwest of line 6 at a depth of about $13 \mathrm{~km}$. The aftershocks extend from just southeast of line 6 to a point $\sim 15 \mathrm{~km}$ northwest of line 6 and locate $2-3 \mathrm{~km}$ shallower on average than the mainshock in the Hauksson et al. (2012) catalog. This depth offset is related to the different relocation methods for the mainshock, which uses a 3D velocity model, and the aftershocks, which use waveform cross correlation (Hauksson et al., 2012). Studies focusing on the 1986 North Palm Springs earthquake, Jones et al. (1986) and Nicholson (1996), show that the mainshock is actually located within the zone of aftershocks.

Dips of reflections (a, b) (Fig. 10b) range from steep (reflection b) to $55^{\circ}-65^{\circ} \mathrm{NE}$ (reflection a), depending on migration model (see also Appendix $\mathrm{C}$ for comparison). For comparison, the focal mechanism of the mainshock dips $45^{\circ}$ NE (Jones et al., 1986; 40-45 NE, Nicholson, 1996), and the main aftershock cluster dips about $55^{\circ} \mathrm{NE}$ (Fig. 10c).

Reflection (f) in Figure 10b appears to correlate closely with the left-lateral Pinto Mountain fault. Reflections from this same fault migrate to a position $\sim 0.5 \mathrm{~km}$ southwest of that shown in Figure 10c after migration using the model of Zelt and Barton (1998; see Appendix C). Diffuse reflections labeled (c) in Figure 10b constitute a steep zone that does not reach the surface, and an upward projection has no fault expression. The southwest-dipping reflection (d) also has no clear interpretation because it does not reach the surface. Reflections (e) project to the ground surface southwest of the Garnet Hill fault, and these may or may not be related to the Garnet Hill fault. Most likely they may represent faulting within the Peninsular Ranges rocks south of the plate boundary. One surprise in this reflection picture is the absence of coherent reflections at depth that correlate with the third branch of the SAF, the Mission Creek fault. The Mission Creek fault is, however, resolved by modeling of magnetic data (Fig. 10d).

We interpreted the buried suture between San Gabriel Mountains rocks and Peninsular Ranges rocks to be the Banning fault (Figs. 10d and 11). However, northwest of Whitewater (W, Fig. 2c), the Banning fault is inactive and lies within San Gabriel Mountains rocks (at the same structural position as the Chocolate Mountains fault to the southwest, see Fig. 6d, or the Vincent thrust to the northwest in the San Gabriel Mountains). Thus, it is possible that San Gabriel Mountains rocks extend southwest of the Banning fault.

On line 6, joint models of gravity and magnetic anomalies were constrained by surface geology, as on line 4, and developed independently of the reflection study (Figs. 10d and 11). Sedimentary rocks were chosen to have a density contrast with basement of between 300 and $400 \mathrm{~kg} / \mathrm{m}^{3}$, and densities and magnetic susceptibilities for basement rocks were guided by measurements of hand samples (Anderson et al., 2004; Langenheim and Powell, 2009). Modeling of 

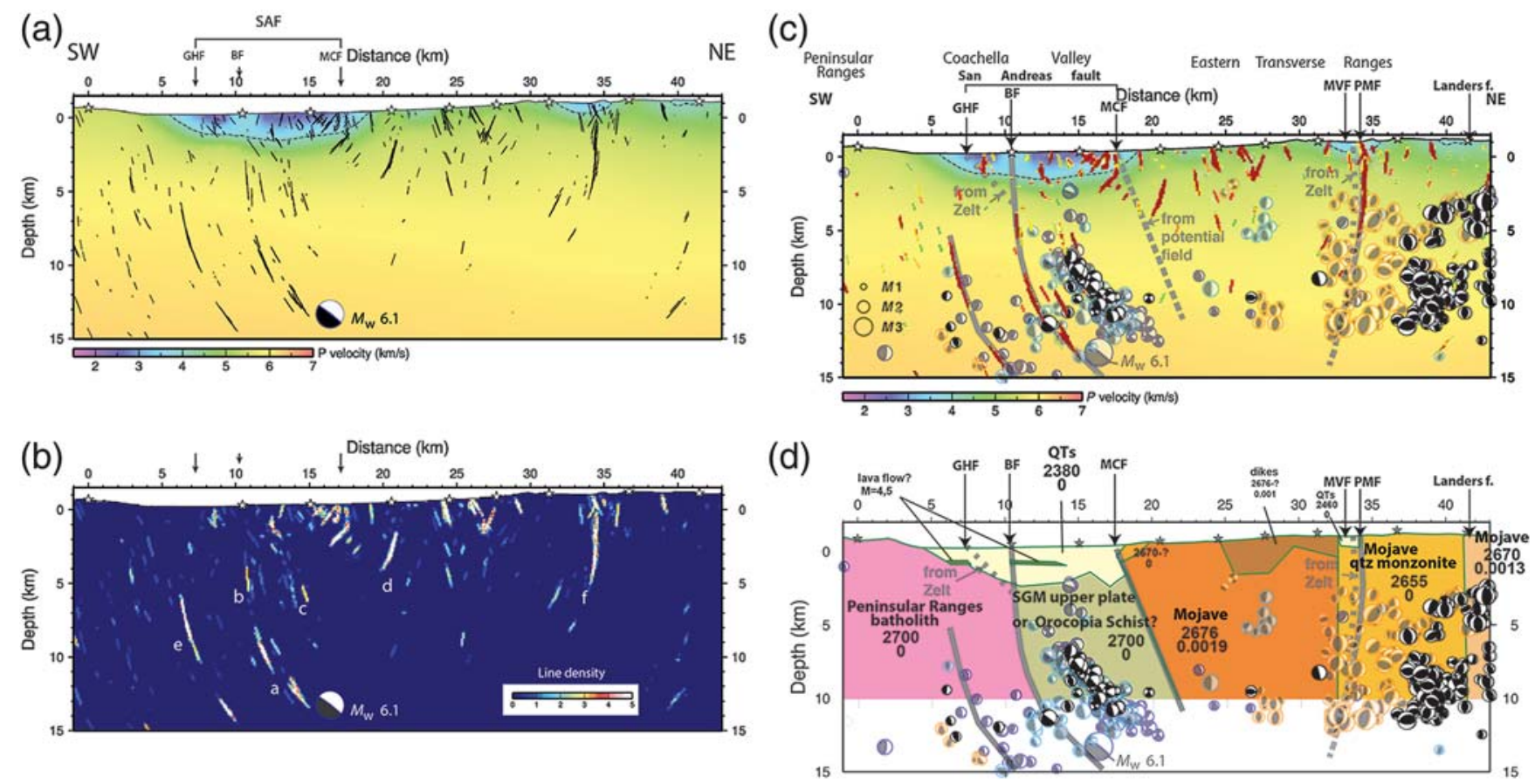

Figure 10. (a) Line-drawings of reverse-moveout reflections from line 6 migrated in the velocity model derived using the inversion algorithm of Hole (1992), supplemented by the SCEC CVM at depths below SSIP ray coverage (see Fig. 8b). (b) Line-drawing density diagram of reflections shown in (a). Line density is the number of migrated line segments in $100 \mathrm{~m} \times 100 \mathrm{~m}$ grid cells weighted by their underlying waveform coherencies. See the Reverse-Moveout Reflections, Earthquakes, and Potential-Field Modeling on Line 6 section for description of labels a-f. (c) Velocity model for line 6 with line-density features from (b) (using slightly different colors for line density), earthquakes (focal mechanisms), and interpreted faults (heavy gray lines). M, magnitude, $M_{\mathrm{w}}$ moment magnitude. Far-hemisphere focal mechanisms (fm) from Yang et al. (2012) using hypocenters of Hauksson et al. (2012): black, fm within $2 \mathrm{~km}$ of line 6; dim gray and blue, fm from 2 to $10 \mathrm{~km}$ northwest of line 6; dim orange and red, fm from 2 to $10 \mathrm{~km}$ southeast of line 6. The focal mechanisms shown are from the period 1981-2011. The focal mechanism solutions displayed are from the two highest-quality categories (A, B) of Yang et al. (2012) and magnitude 2.0 and greater. Stars, shotpoints. Sparsely dashed gray lines are interpreted faults from migration using the velocity model of Zelt and Barton (1998) (see Appendix C). BF, Banning fault; GHF, Garnet Hill fault; MCF, Mission Creek fault; MVF, Morongo Valley fault; PMF, Pinto Mountain fault. (d) Joint model of gravity and magnetic data along line 6. Interpreted faults (gray) and fm are repeated from (c). Density ( $\mathrm{kg} / \mathrm{m}^{3}$; top numbers); magnetic susceptibility ( $10^{-3} \mathrm{SI}$; bottom numbers); for lava flows, magnetization $(\mathrm{A} / \mathrm{m})$ is represented by single numbers $(4,5)$. QTs, Quaternary-Tertiary sediments; SGM, San Gabriel Mountains rocks (see Powell, 1993). For data fits, see Figure 11. (c) and (d) appear to show that the deep part of the SAF dips moderately northeast, and the shallow part of the fault dips steeply, similar to results from line 4.

the gravity data indicates that the basin fill has a thickness of between 2 and $3 \mathrm{~km}$ beneath the central Coachella Valley to account for the 15-20 mGal low (Fig. 11, feature VII), relative to measurements made on basement (VI, VIII in Fig. 11). Features of the observed magnetic anomalies of Figure 11 provide the following constraint on the model: the position of the magnetic high (I) and the gradient (II) requires that the Mission Creek fault dip $\sim 75^{\circ}$ NE. A vertical- or southwest-dipping Mission Creek fault would produce magnetic values that are significantly higher than observed in the data. The gentle gradient II is interrupted by a localized low (III) between the 7 and $14 \mathrm{~km}$ range; the source of this anomaly is not exposed. Reversely magnetized volcanic rock (such as basalt) northeast of the Banning fault could account for this anomaly, given the presence of Miocene basalt just $7-10 \mathrm{~km}$ to the west and also in the southern Chocolate Mountains (after restoring displacement on the SAF). An $\sim 10$ Ma mafic lava flow within the Coachella fanglomerate north of Whitewater (W in Fig. 2c; Allen, 1957; Peterson, 1975) could be present beneath line 6 if this conglomerate package and flow extend $10 \mathrm{~km}$ southeast in the subsurface to line 6 . To account for the magnetic high to the southwest of the low, a normally polarized basalt flow may be present south of the Garnet Hill fault. Such a flow would most likely be in fault rather than depositional contact with Peninsular Ranges rocks. Alternatively, the source of the low (III) and high to the south of it may reside within the basement, but the steep magnetic gradient on the southwest side of (III) suggests that the source is within the valley fill. The magnetic low (VI) in Figure 11 and corresponding subtle gravity low determine a steep magnetic and gravity boundary somewhat southwest of the Pinto Mountain fault and correspond to a change from the deformed rocks of the eastern Transverse Ranges/Mojave Desert to a less deformed quartz monzonite of the Mojave Desert. This feature may correlate with the Morongo Valley fault.

To summarize, reflections (b) and (a) on line 6 appear to show that the shallow part of the Banning fault is steep, but the deep part dips moderately northeast, respectively. The Garnet Hill and Mission Creek faults could represent a 


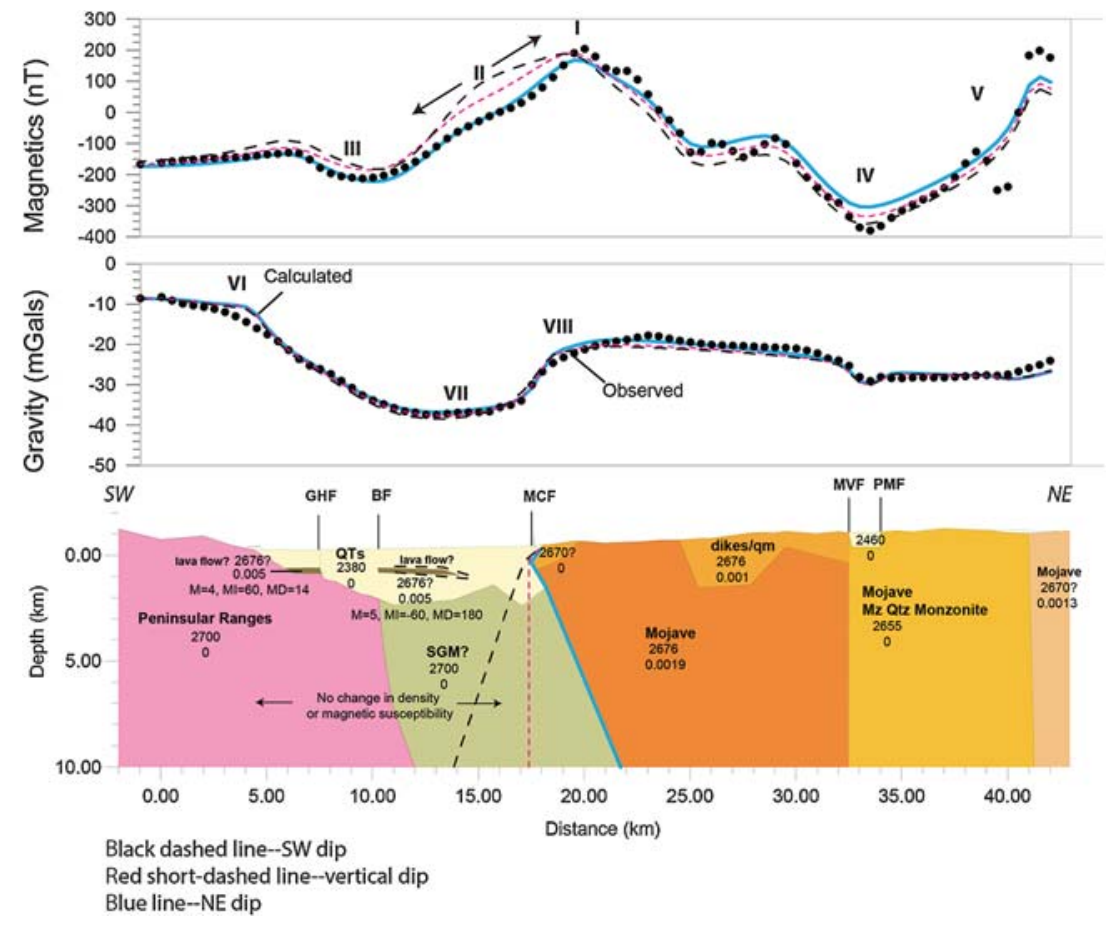

Figure 11. Joint model of gravity and magnetic data along line 6. In data panels, dots are gridded values from observations, and lines are calculated values from various alternate models (see line legend at lower left). Densities $\left(\mathrm{kg} / \mathrm{m}^{3}\right.$, top numbers); magnetic susceptibilities $\left(10^{-3} \mathrm{SI}\right.$, bottom numbers); for lava flows, magnetization $(\mathrm{A} / \mathrm{m})$ is represented by single numbers $(4,5)$; magnetic inclination is $\mathrm{MI}\left({ }^{\circ}\right)$; and magnetic declination is MD $\left(^{\circ}\right)$. See the Reverse-Moveout Reflections, Earthquakes, and PotentialField Modeling on Line 6 section for description of labels I-VIII.

flower-like structure developed along the plate boundary. The Mission Creek fault would join the Banning fault at depths below $15 \mathrm{~km}$ in such an interpretation.

\section{Recalculation of Ground Motion from a ShakeOut-Like Rupture}

Graves et al. (2011) describe ground-motion simulation that was conducted for the Jones et al. (2008) ShakeOut scenario (see details in Appendix D). This simulation was done for a rupture of the southern part of the SAF (Fig. 1) using subsurface fault geometry from the Community Fault Model (CFM) developed by the Southern California Earthquake Center (SCEC; Plesch et al., 2007). This fault geometry is vertical in all places except for a northeast-dipping panel from Indio to San Gorgonio Pass (see Appendix D). Since that time, a number of authors have produced data for and modeled a much longer-dipping panel for the southern SAF, including this study. Fuis et al. (2012) modeled a northeast-dipping SAF from the Salton Sea to the Mojave Desert. Lindsey and Fialko (2013) modeled a northeast-dipping SAF from Indio to the Salton Sea, and Fattaruso et al. (2014) modeled a northeast-dipping SAF from San Gorgonio Pass to the Salton Sea. Model dips in all cases are in the $60^{\circ}-70^{\circ}$ range.

The subsurface geometry of the SAF reported in this article is more complex than the Fuis et al. (2012) geometry.
In the two cross sections examined above, a bend or kink in the fault is seen at a depth of 6-9 km, whereby the fault dips steeply northeast at shallower depths and moderately northeast at greater depths. In contrast, the subsurface geometry obtained by Fuis et al. (2012) is planar in most cross sections. We did not use the more complex geometry interpreted in this article to recalculate shaking, because we have only two locations where the bend or kink in the subsurface SAF is documented, namely on lines 4 and 6 , both of which are in the Coachella Valley. The subsurface geometry of the SAF through the San Bernardino Mountains to the northwest is not known in the detail that we have developed in this study.

For the dipping geometry of Fuis et al. (2012), the recomputed ground-motion simulations yield shorter-period $(T<1 \mathrm{~s})$ shaking along the southern SAF that is locally up to a factor of 2 larger on the hanging wall and locally up to a factor of 2 lower on the footwall, compared to shaking calculated for the 2008 ShakeOut scenario. The pattern of amplification at longer periods $(T>1 \mathrm{~s})$ is more complex due to the effects of rupture directivity. The reader is referred to Appendix D for documentation of this shaking. We speculate that once the subsurface geometry for the entire southern SAF is better constrained and used to recalculate shaking, the results will likely lie intermediate between those presented here and the results from the original ShakeOut scenario.

\section{Discussion}

It is commonly believed that strike-slip faults, including the SAF, are vertical or steeply dipping (e.g., Plesch et al., 2007), although dipping versions are now included as alternate geometries in the SCEC CFM (e.g., Plesch et al. 2010). Fuis et al. (2012) postulated that the SAF in southern California is in most places not vertical, with the SAF from the Mojave Desert into the Salton trough dipping northeast and from the western Mojave Desert to the Carrizo Plain dipping southwest. SSIP was undertaken, in part, to confirm or dismiss the postulated northeast dip of the southern SAF.

Direct reflection imaging of steep faults is rare, with only a few examples in California (e.g., Shaw and Shearer, 1999; Hole et al., 2001; Bleibinhaus et al., 2007). The imaging method of Bauer et al. (2013) represents a promising tool that can be applied to steep faults worldwide. Use of this technique not only images a dipping SAF but also illuminates more than half a dozen additional steep to moderately dipping faults. Our results show that in the northern Salton trough (a) the shallow 
part of the SAF is steep and the deep part dips moderately northeast, and (b) a flower-like structure may be developed largely above SAF. For descriptions of flower structures, see Sylvester and Smith (1976), Harding and Lovell (1979), and Harding (1985). Because the term flower structure is generally applied to a fan-like fault geometry above a steeply dipping fault, we use instead flower-like structure for the fault geometry above our interpreted moderately northeast-dipping SAF.

Flower-like deformation is expected in modeling of rocks surrounding vertical strike-slip, reverse, and normal faults as these faults approach the free surface, owing to the reduction in confining pressure (Ma, 2008, 2009; Templeton and Rice, 2008). The decreased number of earthquakes in the upper few kilometers of the crust (Hauksson, 2015), as well as the decrease in seismic velocity surrounding the shallow portion of some faults (e.g., Cochran et al., 2009; Ben-Zion et al., 2015), may be an indication of changing rheology with decreasing depth, in addition to the free-surface effect. Graves and Pitarka (2004, 2010) modeled the effect of these depth-dependent properties by increasing slip rise time and decreasing rupture speed for fault rupture in the upper few kilometers of the crust. Similar depth-dependent effects were included in kinematic Hayward fault scenarios (Aagaard et al., 2010) and the original ShakeOut parameterization (Graves et al., 2011). More recent spontaneous dynamic calculations for a large San Andreas rupture have included the effects of off-fault plasticity, which suggest these near-fault nonlinear effects can significantly reduce ground shaking levels (Roten et al., 2014). The recent study by Graves and Pitarka (2016) also showed that the heterogeneity of fault geometry and reduced seismic velocity of the shallow near-fault material can scatter higher frequency motions and lead to a homogenization of radiation-pattern effects consistent with observed ground motions. In any case, the development of a flower-like structure above our interpreted dipping SAF is not surprising, and calculated shaking in the region of the flowerlike structure may be affected. However, the flower-like structure interpreted from our study, above about $10 \mathrm{~km}$ for line 4 and above a much greater depth for line 6, originates well below the upper few kilometers where seismicity is reduced and where rheology change has been proposed.

A northeast-dipping SAF has potentially important effects on expected levels of strong ground shaking, particularly within about $25 \mathrm{~km}$ of the fault (see Appendix D). Calculations for a rupture similar to that of the 2008 Great California ShakeOut (Jones et al., 2008), but on a northeastdipping SAF that approximates the geometry reported in this study, yield peak ground accelerations up to a factor of 2 larger on the hanging wall (northeast block) and up to a factor of 2 smaller on the footwall (southwest block) along the portion of the rupture southeast of Cajon Pass, relative to the 2008 rupture model (see Appendix D, Figs. D2 and D3). This change in calculated shaking is directly related to the change in subsurface geometry of the fault, from the Jones et al. (2008) to the Fuis et al. (2012) fault surfaces, and may have important implications for hazard characterization within about $25 \mathrm{~km}$ of the fault. As noted above, the steep- ening of the SAF in the upper 6-9 km, as reported in this study, may reduce the shaking enhancement modeled herein, when this new complexity is taken to account.

Abrahamson and Somerville (1996) characterized the higher shaking amplitudes on the hanging wall for the 1994 M 6.7 Northridge earthquake compared to the footwall, and Fuis et al. (2012) cited higher shaking amplitudes on the hanging walls of the $1986 M_{\mathrm{w}} 6.1$ North Palm Springs earthquake and the $1989 M 6.9$ Loma Prieta earthquake. These earthquakes were reverse, strike-slip, and oblique events, respectively, on dipping faults. Thus, the results of our shaking recalculation are not surprising, namely, that shaking is expected to be stronger on the hanging walls of faults and that fault geometry is important in calculations of ground shaking.

\section{Tectonic Implications}

One might wonder why the SAF is kinked in cross section, as interpreted in this study, with the shallow part of the fault (above 6-9 km) dipping steeply and the deeper part of the fault dipping moderately. We speculate that the SAF changes dip upward to minimize energy in the upper part of the crust where rheology is changing. The concept is that it takes more work to move rock along a longer, dipping fault than along a shorter, steep fault in this region. This proposition could be tested by numerical modeling.

The moderately dipping part of the SAF, below 6-9 km, may be a relict in the Coachella Valley of the dramatic underthrusting of the Pacific plate beneath the North American plate in the region from San Gorgonio Pass to Cajon Pass (Langenheim et al., 2016). The underthrusting in this region has recently been supported and emphasized by analysis of ambientnoise tomography (Barak et al., 2015). In a cross section between San Gorgonio and Cajon Passes, mafic lower crust of the Peninsular Ranges (Pacific plate) appears to underthrust North America by at least $30 \mathrm{~km}$ (Fig. 12a). Our study indicates that the northeast dip of the plate boundary persists southeastward into the Coachella Valley where the surface trace of the SAF approaches an azimuth similar to plate-motion directions (DeMets et al., 2010) and where underthrusting is diminished compared to the region between San Gorgonio and Cajon Passes (Fig. 12b). As Fattaruso et al. (2014) point out, however, a slight mismatch in the strike of the SAF and plate-motion directions in the Coachella Valley gives rise to the compression that produces the Mecca and Indio Hills.

\section{Conclusions}

In this study, we use a multidisciplinary data set that includes steep reflections, potential-field data, and earthquakes to reveal a rather unexpected geometry for the subsurface SAF in the Coachella Valley: above $6-9 \mathrm{~km}$ the fault dips steeply northeast, below that depth it dips moderately northeast. Other nearby faults are also imaged in the upper $10 \mathrm{~km}$, many of which dip steeply and project to mapped surface traces of secondary faults, and these secondary faults may join the SAF at 

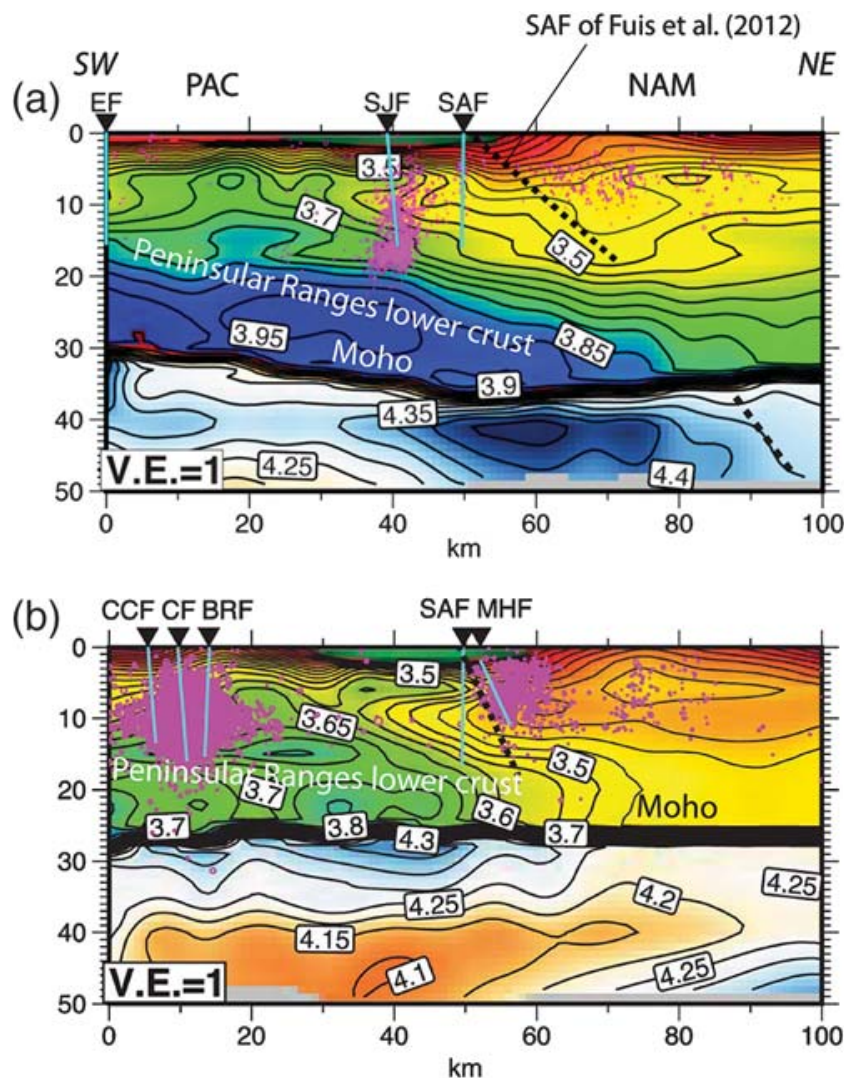

Figure 12. (a) $S$-wave velocity model located northwest of San Gorgonio Pass, modified from Barak et al. (2015, their fig. 6F). Modifications are added label, SAF of Fuis et al. (2012), added heavy black dashed line for plate boundary (SAF) in mantle (after Fuis et al., 2012), added labels, Peninsular Ranges lower crust and Moho. Light blue solid lines, faults from the SCEC Community Fault Model (CFMv5; Plesch et al., 2007). Magenta dots, earthquakes from Hauksson et al. (2012). EF, Elsinore fault; SJF, San Jacinto fault; SAF, San Andreas fault; PAC, Pacific Plate; NAM, North American Plate. Location of cross section is shown in Figure 1 inset map. (b) $S$-wave velocity model located approximately halfway between lines 4 and 6, modified from Barak et al. (2015, their fig. 6C). Modifications are added labels, Peninsular Ranges lower crust and Moho. Symbols as in (a). BRF, Buck Ridge fault; CCF, Coyote Creek fault; CF, Clark fault; MHF, Mecca Hills fault; SAF, San Andreas fault. Cross-section location is shown in the inset of Figure 1. (a) and (b) are reproduced with permission of Geochemistry, Geophysics, Geosystems, a journal of the American Geophysical Union.

depths below about $10 \mathrm{~km}$ to form a flower-like structure. The origin of the two-part dip of the SAF is not clearly known. We speculate that the upper, steep dip is the fault's response to a changing rheology in the near surface and also the fault's response to the free surface. The lower, moderate dip may be a relict of dramatic underthrusting of the North American plate by the Pacific plate in the San Bernardino Mountains, just northwest of the Coachella Valley.

The northeast dip of the SAF will produce shaking enhancement on the hanging wall and shaking reduction on the footwall, each by up a factor of 2 compared to the ShakeOut scenario. However, we modeled shaking using an approximate geometry for the subsurface southern SAF. We speculate that once the subsurface geometry for the entire southern SAF is better constrained and used to recalculate shaking, the results will likely lie intermediate between those presented here and the results from the original ShakeOut scenario.

\section{Data and Resources}

Data used in this study are presented in Rose et al. (2013) and are now archived at the Incorporated Research Institutions for Seismology, Data Management Center. The Southern California Earthquake Center (SCEC) Community Velocity Model, v.4 (http://scec.usc.edu/scecpedia/CVM-S4) is cited in Appendix D and was last accessed in October 2016.

\section{Acknowledgments}

We thank land owners for their cooperation in data collection for this study, without which the Salton Seismic Imaging Project (SSIP) could not have been completed: line 4, Torres Martinez tribe, U.S. Bureau of Land Management (Palm Springs office); line 6, Palm Springs tram, U.C. Irvine, Coachella Valley Association of Governments, and City of Yucca Valley. Please refer to the extensive acknowledgments in Rose et al. (2013) for permissions and assistance we received for SSIP as a whole. We thank R. J. Blakely, W. D. Mooney, K. Knudsen, and two anonymous reviewers for helpful reviews, and numerous colleagues for discussions. SSIP was supported by National Science Foundation (NSF) Grants 0742263, 9742253, and 0927446 and funds from the U.S. Geological Survey (USGS) and Southern California Earthquake Center (SCEC).

\section{References}

Aagaard, B. T., R. W. Graves, D. P. Schwartz, D. A. Ponce, and R. W. Graymer (2010). Ground-motion modeling of Hayward fault scenario earthquakes, part I: Construction of the suite of scenarios, Bull. Seismol. Soc. Am. 100, no. 6, 2927-2944, doi: 10.1785/0120090324.

Abrahamson, N., and P. Somerville (1996). Effects of the hanging wall and footwall on ground motions recorded during the Northridge earthquake, Bull. Seismol. Soc. Am. 86, S93-S99.

Allen, C. R. (1957). San Andreas fault zone in San Gorgonio Pass, southern California, Bull. Geol. Soc. Am. 68, 315-330.

Anderson, M., J. C. Matti, and R. C. Jachens (2004). Structural model of the San Bernardino basin, California, from gravity, aeromagnetic, and seismicity analysis, J. Geophys. Res. 109, no. B04404, doi: 10.1029/2003JB002544.

Barak, S., S. L. Klemperer, and J. F. Lawrence (2015). San Andreas fault dip, Peninsular Ranges mafic lower crust and partial melt in the Salton trough, southern California, from ambient-noise tomography, Geochem. Geophys. Geosys. 16, 3946-3972, doi: 10.1002/ 2015GC005970.

Bauer, K., T. Ryberg, G. S. Fuis, and S. Lueth (2013). Seismic imaging of the Waltham Canyon fault, California: Comparison of ray-theoretical and Fresnel volume prestack depth migration, Bull. Seismol. Soc. Am. 103, 340-352, doi: 10.1785/0120110338.

Ben-Zion, Y., F. L. Vernon, Y. Ozakin, D. Zigone, Z. E. Ross, H. Meng, M. White, J. Reyes, D. Hollis, and M. Barklage (2015). Basic data features and results from a spatially dense seismic array on the San Jacinto fault zone, Geophys. J. Int. 202, no. 1, 370-380, doi: 10.1093/gji/ggv142.

Biehler, S., R. W. Kovach, and C. R. Allen (1964). Geophysical framework of the northern gulf province, in Marine Geology of the Gulf of California, T. H. van Andel and G. G. Shor Jr. (Editors), Mem. Amer. Assoc. Petrol. Geol., Vol. 3, 126-143. 
Bleibinhaus, F., J. A. Hole, T. Ryberg, and G. S. Fuis (2007). Structure of the California Coast Ranges and San Andreas fault at SAFOD from seismic waveform inversion and reflection imaging, J. Geophys. Res. 112, no. B06315, doi: 10.1029/2006JB004611.

Blisniuk, K., K. M. Scharer, W. D. Sharp, R. Burgmann, M. J. Rymer, T. K. Rockwell, and P. L. Williams (2012). Rapid late Quaternary slip on the San Andreas fault zone in the Coachella Valley and the distribution of slip across the Pacific-North America plate boundary, presented at the 2012 Fall Meeting, AGU, San Francisco, California, 14-18 December, Abstract G22B-05.

Cochran, E. S., Y.-G. Li, P. M. Shearer, S. Barbot, Y. Fialko, and J. E. Vidale (2009). Seismic and geodetic evidence for extensive, long-lived fault damage zones, Geology 37, no. 4, 315-318, doi: 10.1130/G25306A.1.

DeMets, C., R. G. Gordon, and D. F. Argus (2010). Geologically current plate motions, Geophys. J. Int. 181, no. 1, 1-80, doi: 10.1111/ j.1365-246X.2009.04491.x.

Dorsey, R. J., and V. E. Langenheim (2015). Crustal-scale tilting of the central Salton block, southern California, Geosphere 11, no. 5, doi: 10.1130/GES01167.1.

Elders, W. A., R. W. Rex, T. Meidav, P. T. Robinson, and S. Biehler (1972). Crustal spreading in southern California, Science 178, 15-24.

Erskine, B. G., and H.-R. Wenk (1985). Evidence for Late Cretaceous crustal thinning in the Santa Rosa mylonite zone, southern California, Geology 13, 274-277.

Fattaruso, L. A., M. L. Cooke, and R. J. Dorsey (2014). Sensitivity of uplift patterns to dip of the San Andreas fault in the Coachella Valley, California, Geosphere 10, 1235-1246, doi: 10.1130/GES01050.1.

Feld, C., J. Mechie, C. Hübscher, J. Hall, S. Nicolaides, C. Gurbuz, K. Bauer, K. Louden, and M. Weber (2017). Crustal structure of the Eratosthenes Seamount, Cyprus and S. Turkey from an amphibian wide-angle seismic profile, Tectonophysics 700/701, 32-59, doi: 10.1016/j.tecto.2017.02.003.

Fialko, Y. (2006). Interseismic strain accumulation and the earthquake potential on the southern San Andreas fault system, Nature 441, 968-971, doi: 10.1038/nature04797.

Fuis, G. S., W. D. Mooney, J. H. Healy, G. A. McMechan, and W. J. Lutter (1984). A seismic refraction survey of the Imperial Valley region, California, J. Geophys. Res. 89, 1165-1189.

Fuis, G. S., D. S. Scheirer, V. E. Langenheim, and M. D. Kohler (2012). A new perspective on the geometry of the San Andreas fault in southern California and its relationship to lithospheric structure, Bull. Seismol. Soc. Am. 102, no. 1, 236, doi: 10.1785/0120110041.

Fumal, T. E., M. J. Rymer, and G. G. Seitz (2002). Timing of large earthquakes since A.D. 800 on the Mission Creek strand of the San Andreas fault zone at Thousand Palms Oasis, near Palm Springs, California, Bull. Seismol. Soc. Am. 92, 2841-2860.

Gardner, G. H. F., L. W. Gardner, and A. R. Gregory (1974). Formation velocity and density: The diagnostic basis for stratigraphic traps, Geophysics 39, 770-780.

Gold, P. O., W. M. Behr, D. Rood, W. D. Sharp, T. K. Rockwell, K. Kendrick, and A. Salin (2015). Holocene geologic slip rate for the Banning strand of the southern San Andreas fault, southern California, J. Geophys. Res. 120, 5639-5663, doi: 10.1002/2015JB012004.

Graves, R., and A. Pitarka (2004). Broadband time history simulation using a hybrid approach, 13th World Conf. on Earthquake Engineering, Vancouver, British Columbia, Paper No. 1098.

Graves, R. W., and A. Pitarka (2010). Broadband ground-motion simulation using a hybrid approach, Bull. Seismol. Soc. Am. 100, no. 5A, 20952123, doi: 10.1785/0120100057.

Graves, R. W., and A. Pitarka (2016). Kinematic ground motion simulations on rough faults including effects of 3D stochastic velocity perturbations, Bull. Seismol. Soc. Am. 106, no. 5, 2136-2153.

Graves, R. W., B. T. Aagaard, and K. W. Hudnut (2011). The ShakeOut earthquake source and ground motion simulations, Earthq. Spectra 27, no. 2, 273-291, doi: 10.1193/1.3570677.

Han, L., J. A. Hole, J. M. Stock, G. S. Fuis, A. Kell, G. M. Graham, N. W. Driscoll, M. J. Rymer, A. González-Fernández, and O. Lázaro-
Mancilla (2016). Continental rupture and the creation of new crust in the Salton trough rift, Southern California and northern Mexico: Results from the Salton Seismic Imaging Project, J. Geophys. Res. 121, 7469-7489, doi: 10.1002/2016JB013139.

Han, L., J. A. Hole, J. M. Stock, G. S. Fuis, C. F. Williams, J. R. Delph, K. K. Davenport, and A. J. Livers (2016). Seismic imaging of the metamorphism of young sediment into new crystalline crust in the actively rifting Imperial Valley, California, Geochem. Geophys. Geosys. 17, 4566-4584, doi: 10.1002/2016GC006610.

Harding, T. P. (1985). Seismic characteristics and identification of negative flower structures, positive flower structures, and positive structural inversion, Am. Assoc. Petrol. Geol. Bull. 69, 582-600.

Harding, T. P., and J. D. Lovell (1979). Structural styles, their plate-tectonic habitats, and hydrocarbon traps in petroleum provinces, Am. Assoc. Petrol. Geol. Bull. 63, 1016-1058.

Hauksson, E. (2015). Exploring the brittle-ductile transition at the base of the seismogenic zone of the crust in Southern California: Implications for crustal rheology, presented at the 2015 Fall Meeting, AGU, San Francisco, California, 14-18 December, Abstract T51H-04.

Hauksson, E., W. Yang, and P. M. Shearer (2012). Waveform relocated earthquake catalog for southern California (1981-June 2011), Bull. Seismol. Soc. Am. 102, 2239-2244.

Hernandez, A., P. Persaud, K. Bauer, J. Stock, G. Fuis, J. Hole, and M. Goldman (2015). Constraints on shallow crustal structure across the San Andreas fault zone, Coachella Valley, Southern California: Results from the Salton Seismic Imaging Project (SSIP), presented at the 2015 Fall Meeting, AGU, San Francisco, California, 14-18 December, Abstract T41A-2859.

Hole, J. (1992). Nonlinear high-resolution three-dimensional seismic travel time tomography, J. Geophys. Res. 97, 6553-6562.

Hole, J. A., R. D. Catchings, K. C. St. Clair, M. J. Rymer, D. A. Okaya, and B. J. Carney (2001). Steep-dip seismic imaging of the shallow San Andreas fault near Parkfield, Science 294, 1513-1515.

Hole, J. A., T. Ryberg, G. S. Fuis, F. Bleibinhaus, and A. K. Sharma (2006). Structure of the San Andreas fault zone at SAFOD from a seismic refraction survey, Geophys. Res. Lett. 33, L07312, doi: 10.1029/ 2005GL025194.

Janecke, S. U., D. Markowski, R. Bilham, J. P. Evans, M. Bunds, J. Wells, J. Andreini, and R. Quinn (2016). The East Shoreline strand of the San Andreas fault and its implications for the next Big One in southern California, Poster Presentation at the 2016 SCEC Annual Meeting, 192.

Jennings, C. W. (1977). Geologic Map of California, California Division of Mines and Geology, Sacramento, California, scale 1:750,000.

Jennings, C. W., and W. A. Bryant (2010). Fault activity map of California, California Geological Survey Geologic Data Map No. 6, map scale 1:750,000.

Jones, L. M., R. Bernknopf, D. Cox, J. Goltz, K. Hudnut, D. Mileti, S. Perry, D. Ponti, K. Porter, M. Reichle, et al. (2008). The ShakeOut scenario, U.S. Geol. Surv. Open-File Rept. 2008-1150, California Geological Survey Preliminary Report 25.

Jones, L. M., L. K. Hutton, D. D. Given, and C. R. Allen (1986). The North Palm Springs, California, earthquake sequence of July 1986, Bull. Seismol. Soc. Am. 76, 1830-1837.

Langenheim, V., N. Athens, D. Scheirer, G. Fuis, M. Rymer, and M. Goldman (2014). Width and dip of the southern San Andreas fault at Salt creek from modeling of geophysical data, California State University Desert Studies Center 2014 Desert Symposium, April 2014, 83-93.

Langenheim, V. E., and E. Hauksson (2001). Comparison between crustal density and velocity variations in southern California, Geophys. Res. Lett. 28, 3087-3090.

Langenheim, V. E., and R. E. Powell (2009). Basin geometry and cumulative offsets in the eastern Transverse Ranges, southern California: Implications for transrotational deformation along the San Andreas fault system, Geosphere 5, 1-22, doi: 10.1130/GES00177.1.

Langenheim, V. E., R. C. Jachens, G. S. Fuis, and S. Barak (2016). Influence of the Peninsular Ranges batholith on the southern San Andreas fault 
system, California, Geol. Soc. Am. Abstr. Progr. 48, no. 4, doi: 10.1130/abs/2016CD-274340.

Langenheim, V. E., R. C. Jachens, J. C. Matti, E. Hauksson, D. M. Morton, and A. Christensen (2005). Geophysical evidence for wedging in the San Gorgonio structural knot, southern San Andreas fault zone, southern California, Geol. Soc. Am. Bull. 117, 1554-1572.

Langenheim, V. E., D. S. Scheirer, N. D. Athens, and G. S. Fuis (2012). Modeling of potential-field data along profiles of the Salton Sea Imaging Project Transects, southern California, 2012 Fall AGU Meeting, Abstract T44A-07.

Lin, G., P. M. Shearer, and E. Hauksson (2007). Applying a threedimensional velocity model, waveform cross correlation, and cluster analysis to locate southern California seismicity from 1981 to 2005, J. Geophys. Res. 112, no. B12309, doi: 10.1029/ 2007 JB004986.

Lindsey, E. O., and Y. Fialko (2013). Geodetic slip rates in the southern San Andreas fault system: Effects of elastic heterogeneity and fault geometry, J. Geophys. Res. 118, 689-697, doi: 10.1029/2012JB009358.

Lizarralde, D., G. J. Axen, H. E. Brown, J. M. Fletcher, A. GonzálezFernández, A. J. Harding, W. S. Holbrook, G. M. Kent, P. Paramo, F. Sutherland, et al. (2007). Variable styles of rifting in the Gulf of California, Nature 448, 466-469.

Lomnitz, C., C. R. Mooser, C. R. Allen, J. N. Brune, and W. Thatcher (1970). Seismicity and tectonics of the northern Gulf of California region, Mexico. Preliminary results, Geofis. Int. 10, 37-48.

Lonsdale, P. (1989). Geology and tectonic history of the Gulf of California, in The Eastern Pacific Ocean and Hawaii, D. Hussong, E. L. Winterer, and R. W. Decker (Editors), The Geology of North America, Vol. N, Geological Society of America, Boulder, Colorado, 499-521.

Ma, S. (2008). A physical model for widespread near-surface and fault zone damage induced by earthquakes, Geochem. Geophys. Geosys. 9, no. Q11009, doi: 10.1029/2008GC002231.

Ma, S. (2009). Distinct asymmetry in rupture-induced inelastic strain across dipping faults: An off-fault yielding model, Geophys. Res. Lett. 36, L20317, doi: 10.1029/2009GL040666.

Mabey, D. R. (1960). Gravity survey of the western Mojave Desert, California, U.S. Geol. Surv. Profess. Pap. 316-D, 73.

Markowski, D. K. (2016). Confirmation of a new geometric and kinematic model of the San Andreas fault at its southern tip, Durmid Hill, southern California, M.S. Thesis, Utah State University, 150 pp.

Matti, J. C., B. F. Cox, R. E. Powell, H. W. Oliver, and L. Kuizon (1983). Mineral resource potential map of the Cactus Spring Roadless Area, Riverside County, California, U.S. Geol. Surv. Misc. Field Studies Map $M F-1650-A$, scale 1:24,000.

Matti, J. C., D. M. Morton, and B. F. Cox (1992). The San Andreas fault system in the vicinity of the central Transverse Ranges province, southern California, U.S. Geol. Surv. Open-File Rept. $92-035449$ pp.

McNabb, J. C., R. J. Dorsey, B. A. Housen, C. W. Dimitroff, and G. T. Messé (2017). Stratigraphic record of Pliocene-Pleistocene basin evolution and deformation within the southern San Andreas fault zone, Mecca Hills, California, Tectonophysics doi: 10.1016/j.tecto.2017.03.021.

Morton, D. M., F. K. Miller, R. W. Kistler, W. R. Premo, C.-T. A. Lee, V. E. Langenheim, J. L. Wooden, L. W. Snee, B. L. Clausen, and P. Cossette (2014). Framework and petrogenesis of the northern Peninsular Ranges batholith, southern California, Geol. Soc. Am. Memoir 211, 61-143, doi: 10.1130/2014.1211(03).

Muffler, L. J. P., and B. R. Doe (1968). Composition and mean age of detritus of the Colorado River delta in the Salton trough, southeastern California, J. Sediment. Petrol. 38, 384-399.

Nicholson, C. (1996). Seismic behavior of the southern San Andreas fault zone in the northern Coachella Valley, California: Comparison of the 1948 and 1986 earthquake sequences, Bull. Seismol. Soc. Am. 86, 1331-1349.

Parsons, T., and J. McCarthy (1996). Crustal and upper mantle velocity structure of the Salton trough, southeast California, Tectonics 15, 456-471.

Persaud, P., Y. Ma, J. M. Stock, J. A. Hole, G. S. Fuis, and L. Han (2016). Fault zone characteristics and basin complexity in the southern
Salton trough, California, Geology 44, no. 9, 747, doi: 10.1130/ G38033.1.

Peterson, M. S. (1975). Geology of the Coachella fanglomerate, San Andreas Fault in Southern California: California Division of Mines and Geology, Special Report 118, 119-126.

Philibosian, B., T. E. Fumal, and R. J. Weldon (2011). San Andreas fault earthquake chronology and Lake Cahuilla history at Coachella, California, Bull. Seismol. Soc. Am. 101, 13-38, doi: 10.1785/ 0120100050

Plesch, A., C. Nicholson, J. H. Shaw, E. Hauksson, and P. M. Shearer (2010). New developments for the SCEC Community Fault Model and its associated fault database, 2010 SCEC Annual Meeting, Palm Springs, California, $261 \mathrm{pp}$.

Plesch, A., J. Shaw, C. Benson, W. A. Bryant, S. Carena, M. Cooke, J. F. Dolan, G. Fuis, E. Gath, L. Grant, et al. (2007). Community fault model (CFM) for southern California, Bull. Seismol. Soc. Am. 97, 1793-1802, doi 10.1785/0120050211.

Powell, R. E. (1993). Balanced palinspastic reconstruction of pre-late Cenozoic paleogeology, southern California: Geologic and kinematic constraints on evolution of the San Andreas fault system, in The San Andreas Fault System: Displacement, Palinspastic Reconstruction, and Geologic Evolution, R. E. Powell, R. J. Weldon II, and J. C. Matti (Editors), Geol. Soc. Am. Memoir, Vol. 178, $1-106$.

Robinson, P. T., W. A. Elders, and L. J. P. Muffler (1976). Quaternary volcanism in Salton Sea geothermal field, Imperial Valley, California, Geol. Soc. Am. Bull. 87, 347-360.

Rose, E. J., G. S. Fuis, J. M. Stock, J. A. Hole, A. M. Kell, G. Kent, N. W. Driscoll, M. Goldman, A. M. Reusch, L. Han, et al. (2013). Borehole-explosion and air-gun data acquired in the 2011 Salton Seismic Imaging Project (SSIP), southern CaliforniaDescription of the Survey, U.S. Geol. Surv. Open-File Rept. 2013-1172 84 pp., 8 appendices, http://pubs.usgs.gov/of/2013/ 1172/ (last accessed May 2017).

Roten, D., K. B. Olsen, S. M. Day, Y. Cui, and D. Fäh (2014). Expected seismic shaking in Los Angeles reduced by San Andreas fault zone plasticity, Geophys. Res. Lett. 41, no. 8, 2769-2777, doi: 10.1002/ 2014 GL059411.

Ryberg, T., C. Haberland, T. Haberlau, M. H. Weber, K. Bauer, J. H. Behrmann, and W. Jokat (2015). Crustal structure of northwest Namibia: Evidence for plume-rift-continent interaction, Geology 43, no. $8,739-742$, doi: 10.1130/G36768.1.

Sahakian, V., A. Kell, A. Harding, N. Driscoll, and G. Kent (2016). Geophysical evidence for a San Andreas subparallel transtensional fault along the northeastern shore of the Salton Sea, Bull. Seismol. Soc. Am. 106, no. 5, 1963-1978.

Schmitt, A. K., A. Martín, B. Weber, D. F. Stockli, H. Zou, and C.-C. Shen (2013). Oceanic magmatism in sedimentary basins of the northern Gulf of California rift, Geol. Soc. Am. Bull. 125, 1833-1850, doi: 10.1130/ B30787.1.

Shaw, J. H., and P. M. Shearer (1999). An elusive blind-thrust fault beneath metropolitan Los Angeles, Science 283, 1516-1518.

Simpson, R. W., R. C. Jachens, R. J. Blakely, and R. W. Saltus (1986). A new isostatic residual gravity map of the conterminous United States with a discussion on the significance of isostatic residual anomalies, J. Geophys. Res. 91, 8348-8372, doi: 10.1029/ JB091iB08p08348.

Sylvester, A. G., and R. R. Smith (1976). Tectonic transpression and basement-controlled deformation in the San Andreas fault zone, Salton trough, California, AAPG Bulletin 60, 2081-2102.

Templeton, E. L., and J. R. Rice (2008). Off-fault plasticity and earthquake rupture dynamics: 1 . Dry materials or neglect of fluid pressure changes, J. Geophys. Res. 113, no. B09306, doi: 10.1029/ 2007JB005529.

White, B. C. (2006). Structural geology of the eastern central Santa Rosa Mountains, Riverside County, California, San Diego, M.S. Thesis, San Diego State University, 38 pp., scale 1: 24,000. 
Yang, W., E. Hauksson, and P. M. Shearer (2012). Computing a large, refined catalog of focal mechanisms for southern California (19812010): Temporal stability of the style of faulting, Bull. Seismol. Soc. Am. 102, 1179-1194.

Zelt, C. A., and P. J. Barton (1998). Three-dimensional seismic refraction tomography; a comparison of two methods applied to data from the Faeroe basin, J. Geophys. Res. 103, no. B4, 7187-7210.
Appendix A

\section{Checkerboard Tests of Model Resolution}

Figures A1 and A2 show checkerboard tests for model resolution along lines 4 and 6 , respectively.
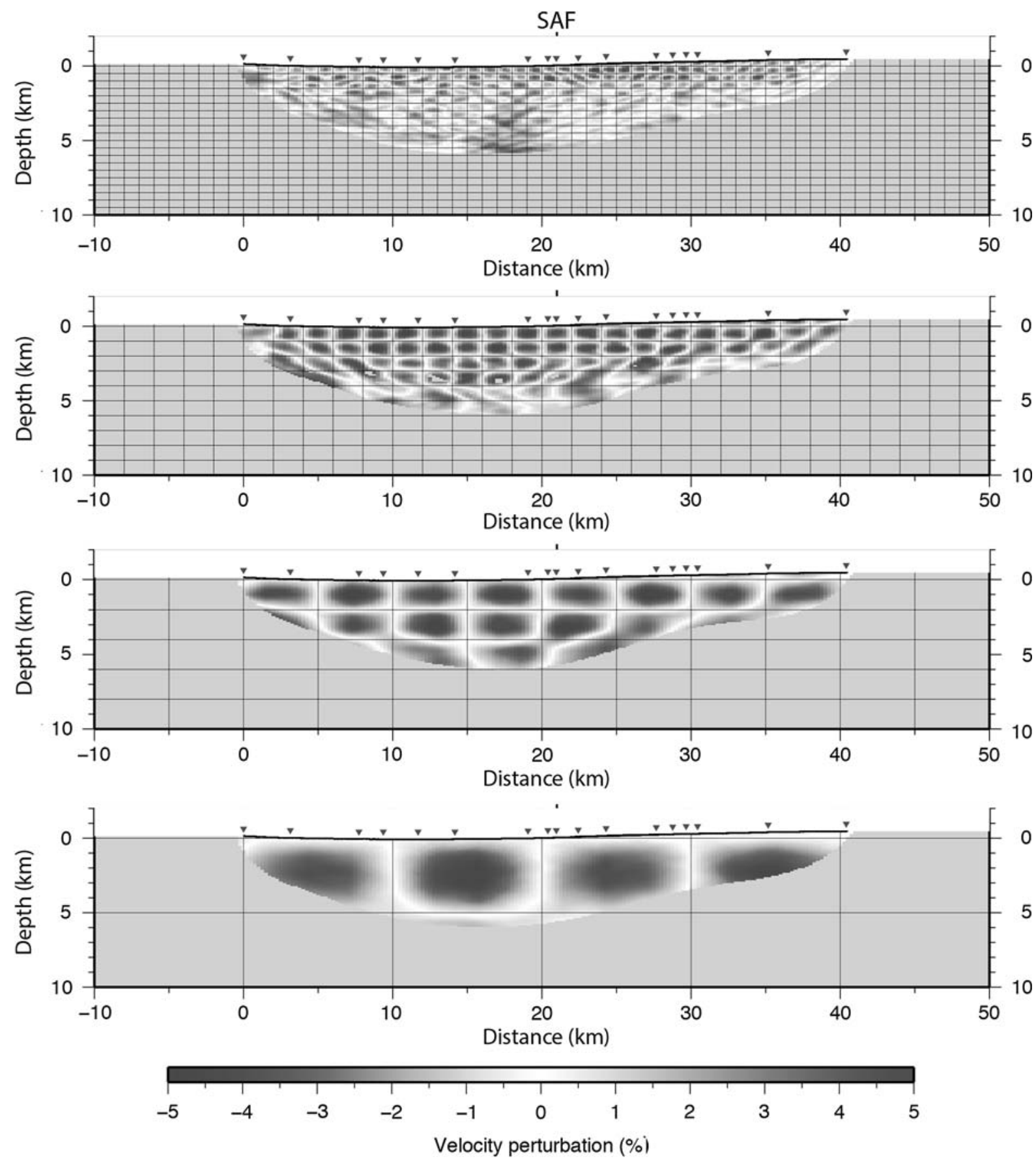

Figure A1. Checkerboard tests of velocity resolution on line 4 for model derived using method of Zelt and Barton (1998) (see Fig. 3c). The test was performed by significantly smoothing the velocity model, adding checkerboard velocity perturbations of $\pm 5 \%$ in rectangular areas of different size (see the four panels), and reinverting first-arrival times using shot and receiver geometry identical to that for the original inversion. From this checkerboard test, one can judge the size and locations of features in the original model that are well resolved. For example, in the top panel, rectangular areas measuring $1 \mathrm{~km}$ wide by $1 / 2 \mathrm{~km}$ deep are well reproduced by the inversion (i.e., not badly smeared) in the upper two layers (i.e., down to a depth of $1 \mathrm{~km}$ ), from about 5 to $30 \mathrm{~km}$ model range. Larger features are resolved to progressively greater depth (lower three panels). 

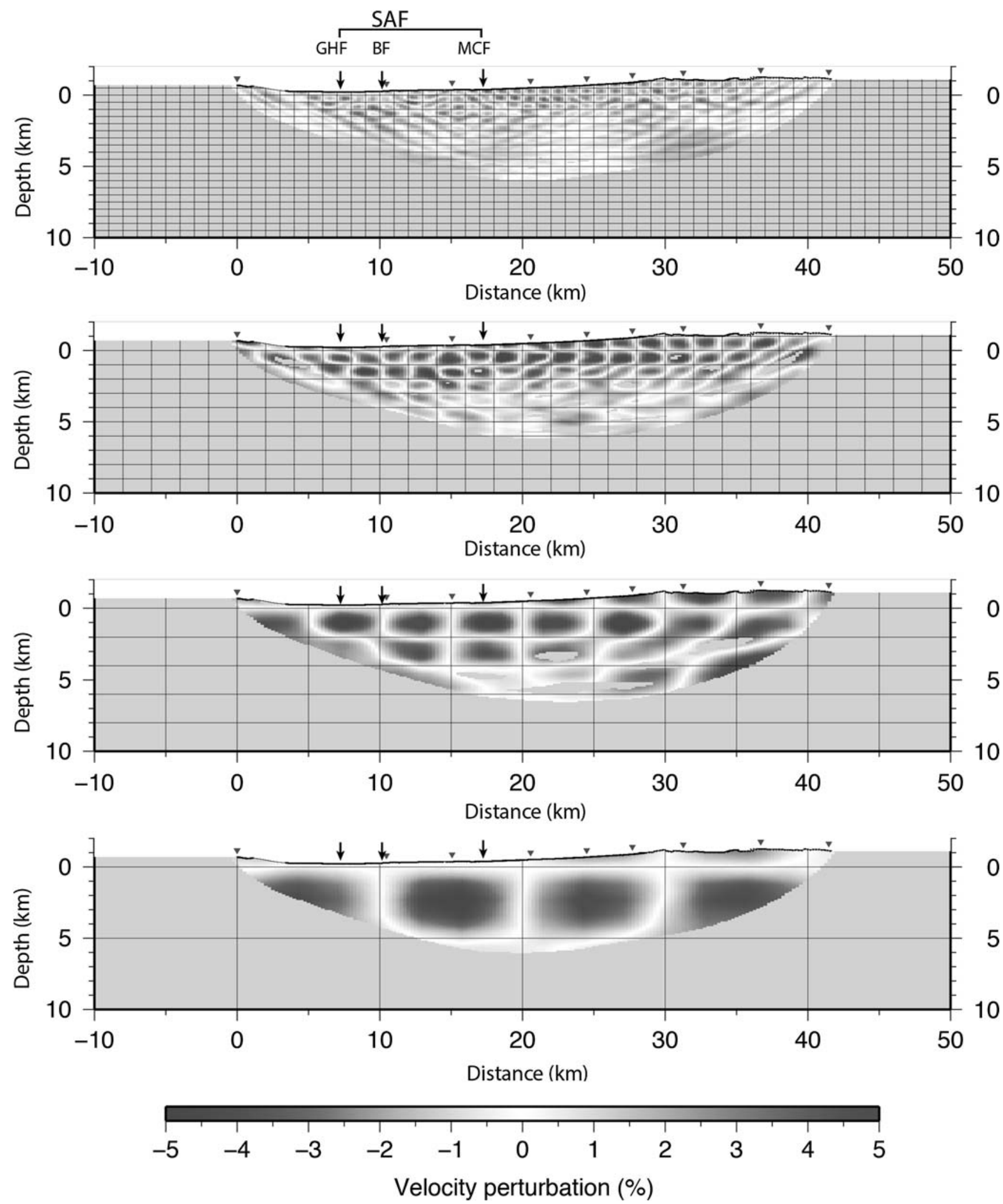

Figure A2. Checkerboard tests of velocity resolution on line 6 for the model derived using the method of Zelt and Barton (1998) (see Fig. 8c). The test was performed as for Figure A1. In this checkerboard test, rectangular areas measuring $1 \mathrm{~km}$ wide by $1 / 2 \mathrm{~km}$ deep are well reproduced by the inversion (i.e., not badly smeared) in the upper three layers of the model from about 15 to $30 \mathrm{~km}$ model range (i.e., down to a depth of $1 / 2 \mathrm{~km}$ ). Larger features are resolved to progressively greater depth (see lower panels). 


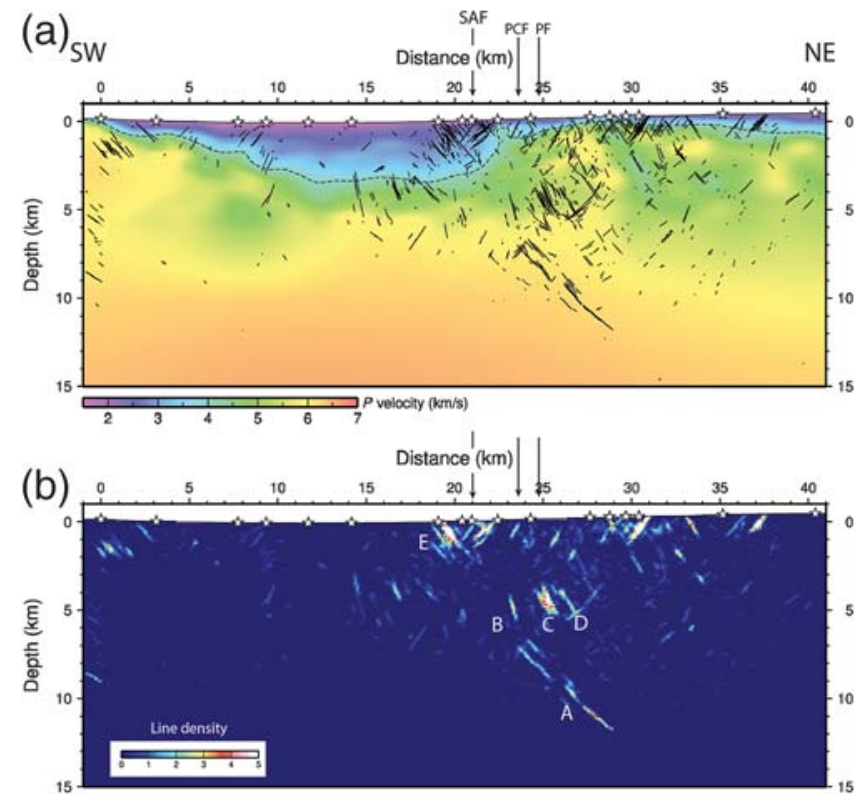

Figure B1. (a) Line-drawings of reverse-moveout reflections from line 4 migrated in velocity model derived using inversion algorithm of Zelt and Barton (1998), supplemented by the SCEC CVM at depths below SSIP ray coverage (see Fig. 3c). White stars indicate shotpoints. (b) Line-drawing density diagram of reflections shown in (a). Line density is the number of migrated line segments in $100 \mathrm{~m} \times 100 \mathrm{~m}$ grid cells weighted by their underlying waveform coherencies. These figures can be compared to Figure $6 \mathrm{a}$ and $b$, in which reflections were migrated in a velocity model derived using the inversion algorithm of Hole (1992). See the Reverse-Moveout Reflections, Earthquakes, and Potential-Field Modeling on Line 4 section for description of letters in (b).

\section{Appendix B}

\section{Migration of Line 4 Reflections Using Alternate Velocity Model}

Figure B1 shows the migration of steep reflections using the velocity model of Figure $3 \mathrm{c}$, derived using the method of Zelt and Barton (1998).

\section{Appendix C \\ Migration of Line 6 Reflections Using Alternate Velocity Model}

Figure $\mathrm{C} 1$ shows the migration of steep reflections using the velocity model of Figure 8c, derived using the method of Zelt and Barton (1998).

\section{Appendix D}

Computation of Ground Motions for the ShakeOut Scenario Rupture Projected onto the Fuis et al. (2012) San Andreas Fault (SAF) Geometry

We recalculated shaking for the 2008 ShakeOut rupture model, but using the subsurface geometry of Fuis et al.
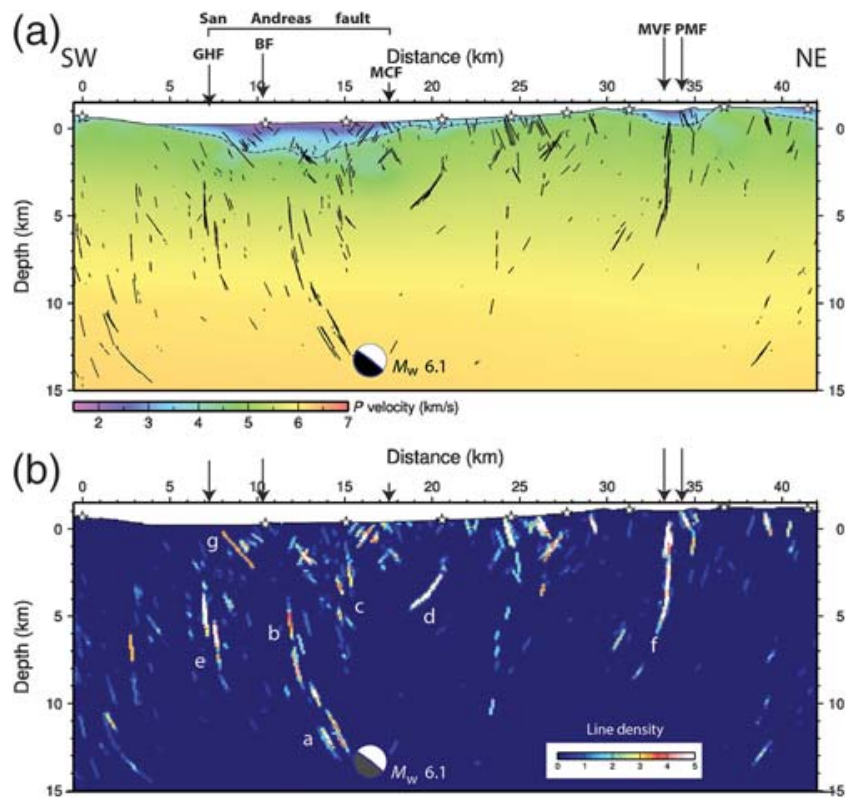

Figure C1. (a) Line-drawings of reverse-moveout reflections from line 6 migrated in velocity model derived using inversion algorithm of Zelt and Barton (1998), supplemented by the SCEC CVM at depths below SSIP ray coverage (see Fig. 8c). White stars indicate shotpoints. (b) Line-drawing density diagram of reflections shown in (a). Line density is the number of migrated line segments in $100 \mathrm{~m} \times 100 \mathrm{~m}$ grid cells weighted by their underlying waveform coherencies. These figures can be compared with Figure 10a,b, where reflections were migrated in a velocity model derived using the inversion algorithm of Hole (1992). See the Reverse-Moveout Reflections, Earthquakes, and Potential-Field Modeling on Line 6 section for description of letters in (b).

(2012). Recalculation of shaking using the more complex subsurface geometry of this study has not yet been attempted; however, we speculate that doing so will likely produce results intermediate between those presented here and the results from the original ShakeOut scenario. The 2008 rupture was reprojected from an along-strike and down-dip coordinate system onto the SAF surface of Fuis et al. (2012) using the hypocenter as a reference point (Fig. D1). Differences in fault width between the Jones et al. (2008) fault geometry and the Fuis et al. (2012) fault geometry result in small slip zones in the current calculation at shallow depth (e.g., the dark patch at 145-185 km in Fig. D1).

The ground motions were calculated using the same procedure as used in the original ShakeOut simulations. The procedure utilizes a hybrid broadband simulation approach (Graves and Pitarka, 2010), in which the lower frequency $(f<1 \mathrm{~Hz})$ ground motions are computed using a fully deterministic 3D methodology, and the higher frequency motions $(f>1 \mathrm{~Hz})$ are computed using a semistochastic methodology. The full kinematic fault rupture is used for both the high- and low-frequency portions of the calculation. The 

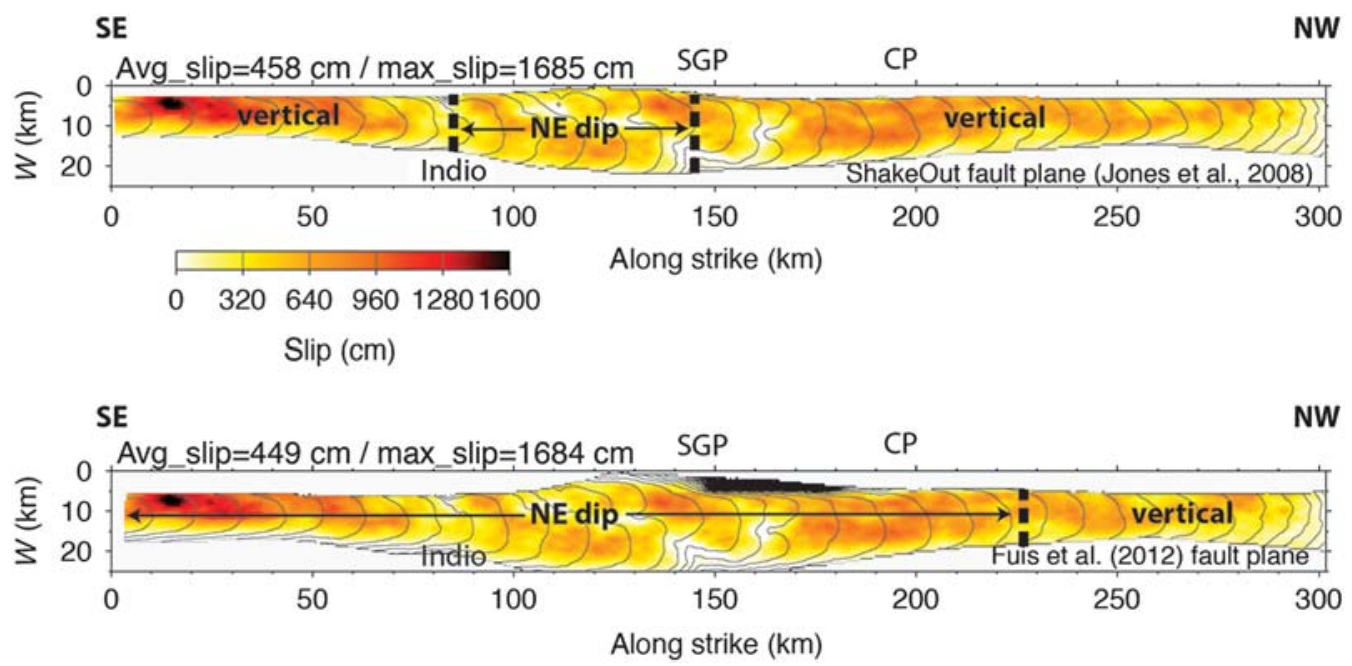

Figure D1. Rupture surface for the Jones et al. (2008) Great ShakeOut earthquake and SAF surface for the southern SAF from Fuis et al. (2012). The Jones et al. (2008) rupture was reprojected from an along-strike and down-dip coordinate system onto the SAF surface of Fuis et al. (2012) using the hypocenter, $0 \mathrm{~km}$ in horizontal coordinates (near Bombay Beach), as a reference point. W, down-dip coordinate. Contours are rupture fronts at $3 \mathrm{~s}$ intervals. CP, Cajon Pass; SGP, San Gorgonio Pass.
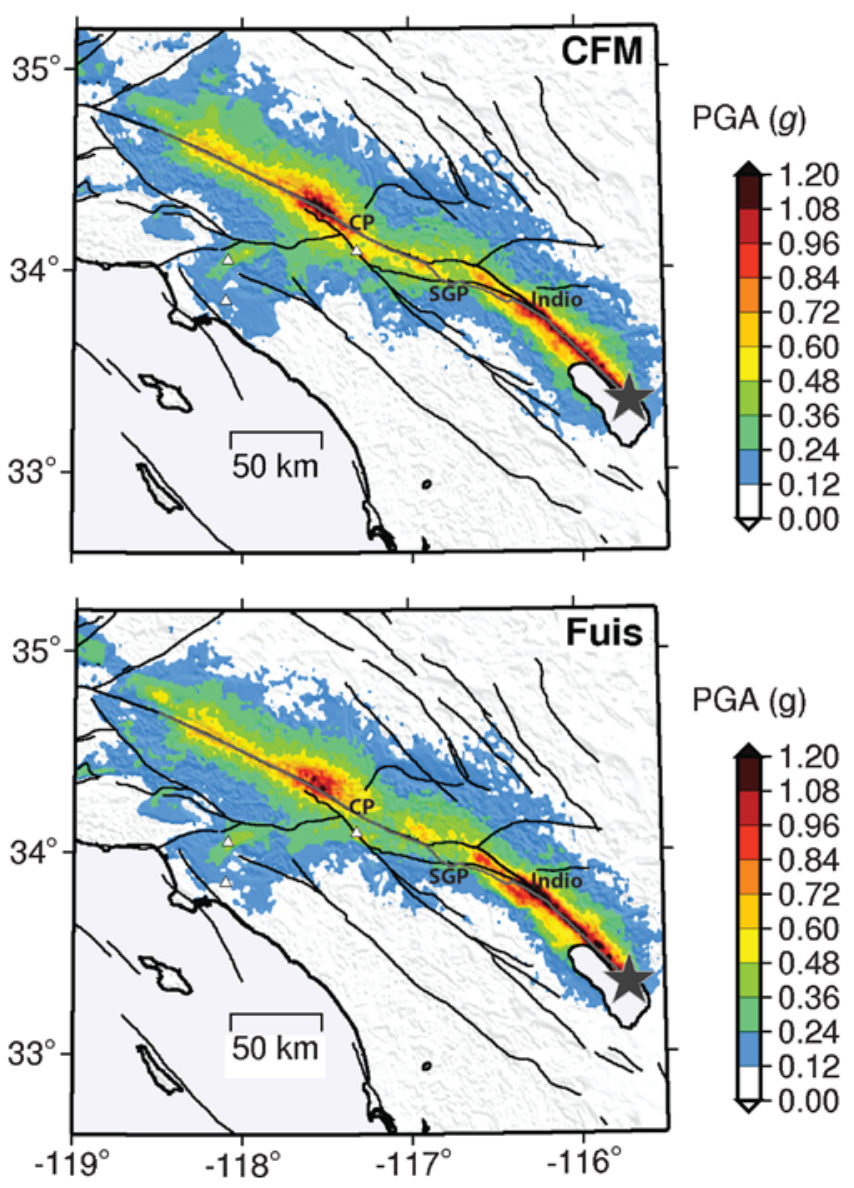

Figure D2. Comparison of shaking (peak ground acceleration [PGA]) calculated using the rupture geometry of Jones et al. (2008; CFM, top panel) and that of Fuis et al. (2012; Fuis, bottom panel). CP, Cajon Pass; SGP, San Gorgonio Pass. Gray star is the ShakeOut epicenter. $g$ is the fraction of Earth's surface gravity.
3D velocity structure used for the low-frequency computation is version 4 of the Southern California Earthquake Center (SCEC) Community Velocity Model (see Data and Resources). For the high-frequency calculation, an average 1D structure is extracted from the 3D model. The simulated motions are also adjusted for site-specific amplification conditions, using a $V_{S 30}$-based approach. For full details of the simulation approach, see Graves et al. (2011).

Results for peak ground accelerations (PGAs, Fig. D2) show only subtle differences between shaking from the 2008 rupture, that used the SCEC Community Fault Model, and rupture using the subsurface geometry of Fuis et al. (2012). When ratios between shaking generated by the two different geometries are taken, however, the differences are more evident (Fig. D3). Along the portion of the fault southeast of Cajon Pass, shaking amplitudes from this study are higher by up to a factor of 2 on the hanging wall of the SAF and lower by up to a factor of 2 on the footwall of the SAF, compared with the original simulation. These effects are seen primarily within about $25 \mathrm{~km}$ of the trace of the SAF. All common measures of shaking, including PGA, peak ground velocity (PGV), and spectral acceleration (SA) at three different periods, show somewhat similar patterns in their ratios (Fig. D3), although the pattern of amplification at longer periods $(T>1 \mathrm{~s})$ is more complex and persists to much farther distance from the fault. The reversal of the amplification pattern northwest of Cajon Pass, with higher amplitudes southwest of the SAF and lower amplitudes northeast of the fault, compared to ShakeOut, is somewhat puzzling because fault geometries are the same between the two shaking models (see Fig. D1). We speculate that rupture directivity differences between the two models southeast of Cajon Pass might explain this reversal, 

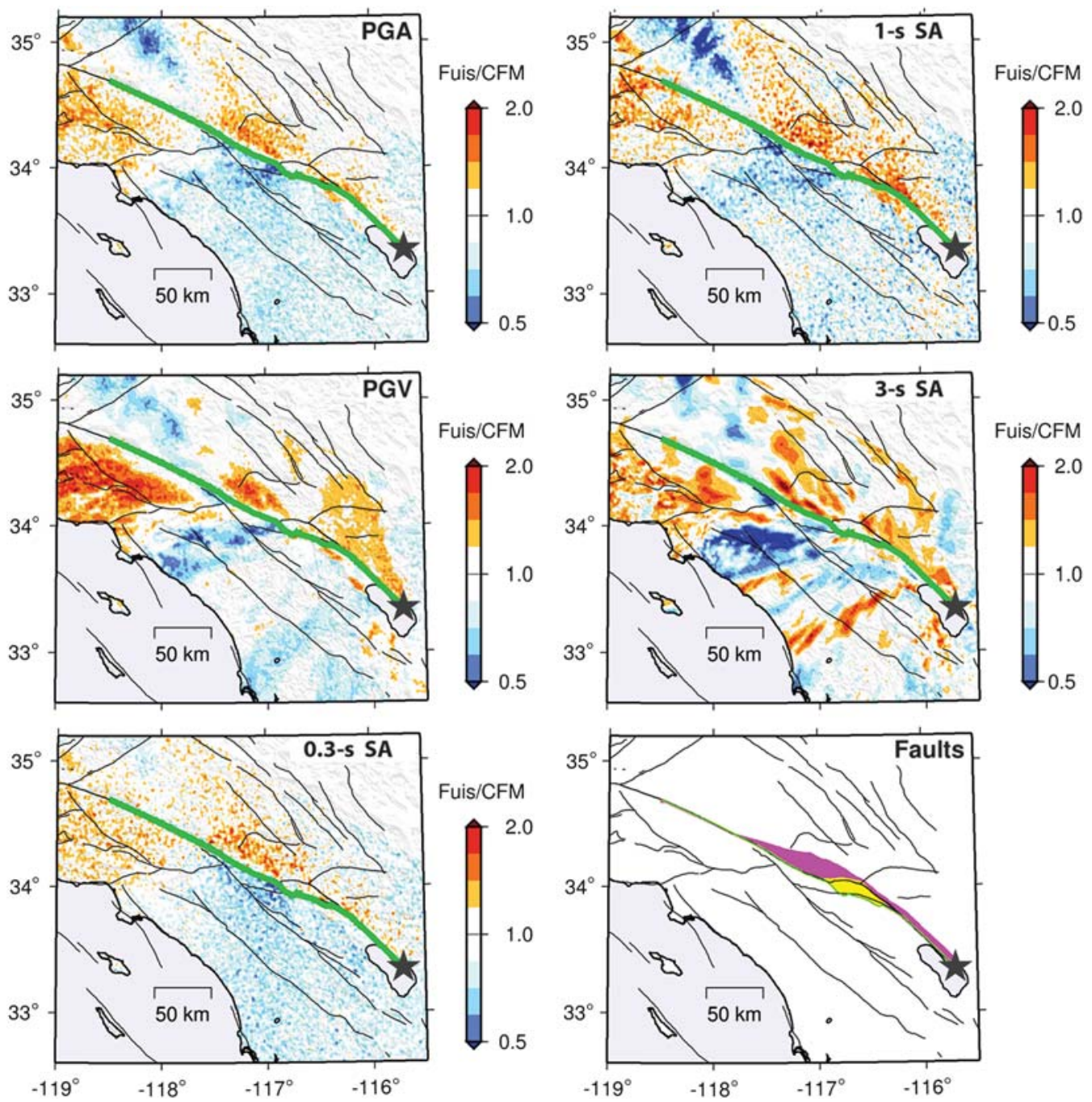

Figure D3. Panels showing various measures of shaking, for which the results of shaking calculated in this study, using the SAF geometry of Fuis et al. (2012), are divided by the shaking calculated using the CFM of Plesch et al. (2007). The ratio is Fuis/CFM. PGA, peak ground acceleration; PGV, peak ground velocity; SA, spectral acceleration shown at three different periods. The lower right panel shows the surface projection of the CFM fault in yellow and the surface projection of the Fuis et al. (2012) fault in purple.

which is consistent with the stronger impact occurring at the longer periods.
California Institute of Technology

Pasadena, California 91125

(J.M.S.)

Virginia Polytechnic Institute and State University Blacksburg, Virginia 24061

(J.A.H.)

U.S. Geological Survey (USGS)

Pasadena, California 91125

(R.W.G.)

Telegrafenberg

D-14473 Potsdam

Germany

(K.B., T.R.)

Manuscript received 10 October 2016; Published Online 4 July 2017 